Meta

Journal des traducteurs

Translators' Journal

\title{
Bibliometric Analysis of Index Translationum
}

\section{Anatolij JA. Šajkevič}

Volume 37, numéro 1, mars 1992

La traduction en Russie : théorie et pratique / Translation in Russia: Theory and Practice

URI : https://id.erudit.org/iderudit/004017ar

DOI : https://doi.org/10.7202/004017ar

Aller au sommaire du numéro

Éditeur(s)

Les Presses de l'Université de Montréal

ISSN

0026-0452 (imprimé)

1492-1421 (numérique)

Découvrir la revue

Citer cet article

Šajkevič, A. J. (1992). Bibliometric Analysis of Index Translationum. Meta, 37(1), 67-96. https://doi.org/10.7202/004017ar

\section{Résumé de l'article}

À l'aide de statistiques produites à partir des données de l'Index Translationum, on brosse un tableau général du volume, de la dynamique et de la structure de la traduction dans le monde. Sont analysés, entre autres, l'importance de l'activité traductionnelle, les principales langues traduites, les thèmes et les auteurs les plus traduits. 


\section{BIBLIOMETRIC ANALYSIS OF INDEX TRANSLATIONUM}

ANATOLIJ JA. ŠJKEVIČ

Terminology Laboratory, USSR Translation Center, Moscow, USSR

\section{Résumé}

$\dot{A}$ l'aide de statistiques produites à partir des données de l'Index Translationum, on brosse un tableau général du volume, de la dynamique et de la structure de la traduction dans le monde. Sont analysés, entre autres, l'importance de l'activité traductionnelle, les principales langues traduites, les thèmes et les auteurs les plus traduits.

Translated literature is an important component of cultural life of society, and translation processes should be studied not only from the linguistic point of view, but from the point of view of sociology as well. Since 1948 UNESCO has been publishing an international annual bibliography called Index Translationum. Some statistical tables, based on Index Translationum, are published in UNESCO Statistical Yearbook.

Index Translationum is a huge mine of information, however, it has not been the object of a comprehensive analytical study. This paper is an attempt to give a first general impression of the volume, dynamics, and structure of the world output of translated books. ${ }^{1}$

Index Translationum is composed of materials presented by national bibliographic organizations of the UNESCO-member-countries. The number of participating countries stabilized by the mid-fifties, therefore the period to be analyzed is from 1955 to 1983 (the last year for which the data were published).

The manner of preparation of Index Translationum involves some usual drawbacks of large bibliographies: 1) irregularities, and 2) omissions. The first drawback is overcome by using five-year periods as convenient time limits. The second obstacle was left unchallenged: the immense task of going through national bibliographies seems insurmountable at present.

Our plan is to discuss the general output of translated books, the original languages, the thematic composition and most translated authors.

\section{GENERAL OUTPUT OF TRANSLATED BOOKS}

The data of overall translation activity are given in Table 1 . No attempt was made to compensate the omission of some countries in the world total. The only exception is the case of the Netherlands, where the data for 1980-1983 are missing, the data for 19751979 were extrapolated to the next period and were included in the world total.

The growth of the volume of publication of translated books seems impressive: in 1958 it amounted to 29,213 , in 1978 it reached 57,147, i.e., it almost doubled in twenty years. After 1978 the growth slowed down. However, if we look at the proportion of translated books (PTB) in the whole mass of published books we come to a different conclusion: the world figure of PTB stays stable at some $9 \%$ with slight variations, not exceeding $0,7 \%$. The most spectacular figures of growth of translation activity (as in FRG or Spain) usually reflect the general book publication activity. 
There are many factors that favour or hinder the amount of translation activity: the size of the country, the linguistic situation, the stage of the cultural development of the nation, the specific traditions and others.

The size of the country (or rather - the size of the reading public) is evidently connected with the translation activity. On the one hand, a small country needs a greater number of translations, so as not to lag behind larger countries. On the other hand, a larger country can create a workforce of translators from various languages, which is not easy for a small country. The relation of PTB and the size of the country is shown in Fig. 1. We see that on the whole the two parameters are inversely related, although the relation is far from linear.

The next factor that should be mentioned is the linguistic situation in the country. The other factors being equal, a multilinguistic country needs more translations. Indeed, Yugoslavia or Czechoslovakia publish more translated books than unilinguistic Poland or Hungary.

In most countries of the world the PTB stays at one level throughout the period considered. The only example of ever-growing PTB (from $8 \%$ to 14\%) is German Democratic Republic. There are a few examples of decline in PTB. In the case of Yugoslavia (from 19\% to 12\%) and Czechoslovakia (from 20\% to 12\%) the general decline is due to a sharp fall in internal translations (from one national language of the country to another). An interesting example of lowering PTB is seen in Israel: 1960-1964 $39 \%, 1965-1969$ 24\%, 1970-1974 17\%, 1975-1979 14\%. Here we observe a certain phase of national cultural development. At a certain stage of the development of a nation it becomes evident that the accumulated cultural values and workforce are not adequate to the task of modernization. The gap between the modern cultural demands and the resources is filled with numerous translations. Further accumulation of cultural experience of other nations makes the need for translation less acute. The number of translations begins to decrease. Analogous examples are well known in the world history (e.g. the Russia of the 18th century). Perhaps, the same factor caused a decline in PTB in South Korea (from $9 \%$ to $2,5 \%$ ), although in this case the fact might be explained by a return to that rather vague factor which we have called specific traditions, namely a certain cultural "isolationism," also observed in Thailand or Singapore (PTB is less than 2\%). To some extent the same isolationism is demonstrated by Anglo-Saxon countries. Their low PTB is only partly explained by the fact that English is now a major source of translations, and that consequently Britain and the United States need half as many translations as other countries.

The opposite is true of the three large countries of continental Europe: Italy, Spain and FRG. Their "involvement" in the world's common culture is very high.

Explaining this or that level of translation activity one should sometimes go outside the borders of the country analyzed: a country may live in the "cultural shadow" of a senior relative of the same language. The senior partner takes upon itself a greater burden of providing cultural food for the speakers of that language irrespective of the country where they live. This is the case of FRG and Austria, Egypt and other Arab countries, Spain and most countries of Latin America.

\section{ORIGINAL LANGUAGES}

We shall use the term "original language" so as not to confuse it with "source language." In most cases the two coincide, but very often the translation is actually made from a language other than the original language. It would be extremely toilsome to keep 
the track of translation paths (sometimes purposefully obscured) whereas doubts as to the identity of the original languages are very rare.

The term linguistic spectrum will denote the proportion of specific original languages in the total sum of translated books in a given country or in the world at large. We shall always give the corresponding figures per mille.

The data of the world linguistic spectrum are given in Table 2 .

The world linguistic spectrum changes very slowly. The main tendency is the growth of the proportion of English - it was 362 in 1960s, grew to 399 in the 1970s and still more to 426 in $1980-83$. It is clear that we should expect a corresponding $10 \%$ decline in all other languages. The deviations from the expected figure are few: growth of Italian (from 24 to 28) and Arabic (from 3,7 to 4,8), and a sharp decline of Czech (from 24 to 10) and Bengali (from 3,3 to 1,3), both due to the fall in internal translations in Czechoslovakia and India. A significant decline of Russian outside the borders of the USSR is observed in 1980-83 (47 as compared to 86 in the 1970s).

An original language may occupy a definite niche in the world's common cultural heritage. Some impressions in that direction may be obtained through the analysis of linguistic spectra of the divisions of Universal Decimal Classification (the information in Index Translationum is grouped under the UDC headings). The analysis of Table 3 shows that there are 3 languages active in all the 9 classes; they are English, French and German. Certainly, there are some individual preferences: e.g. pure science and literature in the case of English; philosophy, religion and arts are characteristic of French. The same are preferred by German, which also gives much in applied sciences. The Russian language shows the same universality (keeping prize positions in the list) with the notable exception of religion where it comes a poor 14th. The three classical languages (Greek, Latin, Sanskrit) are very important in religion (156) and philosophy (64) and very modest in literature (17). Latin and Greek have some importance in history (25). Italian and Dutch contribute much to arts (98) and religion (64). The specific contribution of SerboCroatian and Albanian is social sciences (51), while the other East European languages are important in four classes: social sciences (78), pure science (85), applied sciences (93), arts (89). Of course, these fields in Eastern Europe are to a great extent the product of "self-induced" importance: the translations are made in the country of original language not on order from outside, but just to draw attention to itself and keep the world informed. All other languages are associated mostly with the 8th class (literature).

The part played by a specific original language varies little with time. We should mention three facts. First, the decline of English in the field of social sciences (from 300 to 260), which is quite contrary to the general trend of that language. Second, the growth of the proportion of French, Spanish and Italian in applied sciences (from 90 to 140). And third, the sharp rise of Russian in pure science (from 230 to 300), in history and geography (from 85 to 150), and especially in social sciences (from 240 to 330 ). We will see later that this rise is mainly due to an increase in the translations of school textbooks and partly to a growth of proportion of books by official leaders.

The linguistic spectra differ considerably from country to country (see Table 4). Is there any order in this picture, or just a chaotic variation of individual spectra? To answer this question we shall need a measure of similarity of spectra. For this purpose let us introduce the following expression: 
(1)

$$
S_{A B}=\frac{\sum d_{i} \cdot p_{i}(\min )}{\sqrt{\sum d_{i} \cdot p_{i}(A) \cdot \sum d_{i} \cdot p_{i}(B)}}
$$

where:

$\mathrm{p}_{\mathrm{i}}$ - the proportion of parameter $\mathrm{i}$ in the spectrum;

$\mathrm{p}_{\mathrm{i}}$ (min) - the lesser of the values of $\mathrm{p}_{i}$ in the compared spectra $\mathrm{A}$ and $\mathrm{B}$

$\mathrm{d}_{\mathrm{i}}--\ln \left(\overline{\mathrm{p}}_{\mathrm{i}}\right)$ (where $\overline{\mathrm{p}}_{\mathrm{i}}$ is the mean value of $\mathrm{p}_{\mathrm{i}}$ for the population analyzed).

The expression (1) will serve as a similarity measure for any spectrum, including those that will be discussed later.

In the particular case of linguistic spectra the raw data of Table 4 were modified to allow for the trivial fact of a country's avoidance of translation from its own original language. The actual number of titles was increased by a hypothetical number of books translated from the original language of the country calculated on the basis of the world total of the language and the country's share in the world's sum of translated books. English being the world's major source of translations, the countries most affected by this correction were Britain and the United States. Country-to-country similarity measures served as a basis for a map of countries clustered according to their relation to original languages (see Fig. 2, where double lines correspond to $S \geq 0,9$, single lines to $S=0,80$ $-0,89$, and dotted lines to $S=0,75-0,79$ ).

Fig. 2 is a clear evidence of three big clusters. The upper left part of the map is occupied by five Scandinavian countries with an extraordinary proportion of English and Scandinavian languages. The lower part represents nine East European countries with a very high proportion of Russian and very low proportion of English. Israel and India are outside this cluster, they are to some extent united by a rather low proportion of English and a moderate proportion of Russian. The largest cluster in the center of the map includes most countries of the world with only minor deviations from the world's linguistic spectrum. The unity of the central cluster is evident although some subclusters are visible in the map. They are 1) the countries of the Far East, Egypt and Mexico; 2) the Mediterranean countries, Brazil and Argentina (with a very high proportion of Romance languages); 3) the United States and Britain.

On the whole the linguistic spectra of individual countries are stable, yet in some regions the changes do occur. It is interesting to follow the dilution of the East European cluster in 1980-83. The proportion of Russian grew in the USSR (from 494 in the preceding decades to 553) and in Czechoslovakia (from 248 to 272), it dropped drastically in Bulgaria (436-333), Yugoslavia (100-78), Albania (276-204), and especially in Romania (140-46). The proportion of English grew in Hungary (98-146) and in Bulgaria (79-138).

\section{THEMATIC SPECTRA}

The thematic spectrum is the proportion of large thematic groups (in our case major UDC headings) in the sum of translated books published. The data are given in Tables 5 and 6 . Unlike linguistic spectra, thematic spectra may change rapidly over time. Class 9 (history and geography) is the only group with almost monotonic trend (decline). It seems that 1980 witnessed a break with the past especially in classes 3, 5,7 and 8 . Before that date classes 3, 5, 7 had been growing, while class 8 had been declining.

The eight classes of UDC form two distinct groups according to their PTBs. The group of high PTB includes classes 1 - philosophy (17-20\%), 8 - literature (18-21\%), 2 - religion (12-15\%) and 9 - history and geography (10-13\%). These classes may also 
be termed "traditional," they include many popular books (sometimes many centuries old). The group of "modern" classes are characterized by low PTB (3-9\%). Interestingly enough the change of trends of these two groups occurred around 1980. The proportion of "modern" groups changed as follows: 1955-59 - 268, 1960-64 - 275, 1965-69 $300,1970-74-331,1975-79-349,1980-83-314$.

A hypothesis of thematic clusters of countries becomes quite plausible in the light of Table 6 with its varieties of thematic spectra. The same similarity measures that has been used for the comparison of linguistic spectra proved effective in clustering countries according to their thematic spectra. Three clusters are seen in Fig. 3 (1960-64 period). The first cluster comprises the countries of Northern and Central Europe (Portugal and South Africa as well) with a very high proportion of Class 8 (literature) and very low proportion of Classes 3 and 5. The second cluster includes eight countries of Eastern Europe with an extremely high proportion of Classes $3,5,6$.

The dynamics of thematic spectra are represented in Table 7 and in Figs. 4 and 5. Let us follow the tracks of some of the major UDC headings in their geographic distribution. The high proportion of Class 1 (philosophy) is a permanent feature of Brazil and Argentina; since 1965 it grew in Mediterranean countries; and after 1975 the growth is observed in FRG, Austria and Switzerland.

There are at least three distinct groups of countries if judged by the evolution of Class 2 (religion). First, we observe constant and very significant growth of this class in Middle Eastern and South Asian countries, starting from a high level it more than doubled by the 1980s. An even more spectacular rise is observed in three countries of Eastern Europe - Poland, GDR, Yugoslavia - , but here the starting point was very low, so that they barely reached the average level. The third group is North America and the extreme West of Europe where the proportion of religion is very high, but decreases with time.

The grouping of countries according to the evolution of Class 3 (social sciences) follows the socio-political lines. In the 1950s Eastern Europe differed greatly from the rest of the world, but in the 1970s the paths parted: most countries showed some decrease, while in the USSR Class 3 kept on growing. As far as the West is concerned there was constant growth since 1965 till 1980, when a sharp decrease followed.

The same parting of ways is seen in the field of pure sciences. The USSR increased the proportion of this class whereas the other countries of Eastern Europe witnessed here a $40 \%$ drop.

A curious transformation took place in the sphere of applied sciences. Eastern Europe, the leader at the beginning of the period under consideration, showed constant decrease, while the West and Japan almost doubled the proportion of this class. The two groups changed their positions.

All these changes brought about a considerable reshaping of thematic clusters. By 1975-79 (Fig. 4) the North European cluster with an exceptionally high proportion of Class 8 (literature) had lost FRG, Austria and Belgium, but had included GDR. Portugal had moved to another quarter to build a bridge between the East European cluster and the East Mediterranean subcluster (Turkey, Greece, Israel, Egypt). The border between Eastern Europe and the main cluster had lost its sharpness (Poland may be considered a part of two clusters). The final map of 1980-83 (Fig. 5) shows amalgamation of former clusters. There are no definite borders now. Of course, the picture is not a chaotic net of interrelation, the map suggests a field structure rather than well-defined clusters opposed to each other. Fig. 5 may authorize the following conclusion: the 1980 s witnessed considerable thematic convergence of countries of the world. 


\section{AUTHORS}

To get a deeper understanding of chronological and geographic variations in the publication of translated books, the information on 1000 most translated authors was processed. Some results are given in Table 8.

The analysis of the changing fortunes of the 1000 authors calls for a certain reclassification of material. The UDC (convenient for bibliography and library practice) does not show certain aspects which might prove vital for our study. Certainly, the task of assigning an author to a group may be much more difficult than the corresponding task in the case of a book. Some decisions seem arbitrary, but in a statistical study individual errors are of minor importance unless they are systematic.

First of all, it would be useful to isolate all the authors of Antiquity that are the necessary part of classical education. With the exception of Aesopus (who belongs to children's literature) classical authors form a coherent whole. Their proportion in the total sum of 1000 most translated authors is rather stable, though it decreased after 1974 (from 25 per mille to 18 in 1975-79).

A quite distinct group is formed by the translated books of political leaders (living or dead). The major authors here are Lenin ( 809 translated books for the 29 years analyzed), Brežnev² (1986), Hruščev (1 194), Ceauşescu (770), Stalin (402), Hoxha (310), Živkov (293), Tito (286), lesser figures are Gheorghiu-Dej (114), Kardelj (191), Kosygin (173), Ponomarev (118), Rašidov (132), Suslov (186). The bulk of the publications of this kind is centered in the author's own country. Besides the communist countries this feature is typical of India (Gandhi -312 , Nehru - 151). As a rule transition from on leader to another is very sharp, a kind of a "switch": Stalin: 1955 100 books, 1957 - 6; Hruščev: 1963 - 55, 1965 - 4; Brežnev: 1964 - none, 1965 46.

Typologically similar are translations issued by the Holy See (Joannes XXIII, Paulus VI, Joannes Paulus II). On the other hand typologically different is the case of Mao Tse-tung (712) and Kim Il-sung (131), as well as Stalin after 1956. These authors are extensively published outside their own countries (China and North Korea do not provide information for Index Translationum).

The analysis of individual authors helps to differentiate UDC classes. The philosophy proper (without ancient philosophers) includes 25 authors (in decreasing order): Russell, Nietzsche, Kierkegaard, Hegel, Teilhard de Chardin, Kant, etc. In the 1960 s the group makes up 2,3\% of the total of the 1,000 authors (hereafter - TTA), in 1975-79 it was only 1,3\%. An important distinction between serious and popular literature should be introduced here. Russell is, surely, "popular" which explains his high rating in the group. This distinction will go through all the following groups (both in sciences and in fiction). The two kinds of literature sometimes differ in their evolution, their geographic distribution and usually in the mean date of birth (MDB) of their authors. ${ }^{3}$ For example, the MDB of "serious" philosophy is 1775 , while for "popular" philosophy it is 1888. The ten authors in psychology (Freud, Piaget, Jung, Eysenck and others) gradually increased their proportion: $0,4 \%$ of TTA in the 1950 s and $1,2 \%$ in the 1970s. Permanent growth is also characteristic of a curious no man's land between psychology and exotic religions. Here we find Steiner, Vivekananda, Lobsang Rampa, Krishnamurti, Aurobindo. This group doubled its proportion by the late 1970s. The same rate of growth was shown by Indian (Puranas, Vedas) and Muslim tradition (Qoran, al-Ghazzali, Maudodi).

The Christian religious tradition was represented by 4 groups with peaks at different moments: 1) the Bible makes up some $2 \%$ of TTA, 2) "serious" theology (Augustinus, Aquinas, Luther, Barth, Rahner and 14 others) with its peak (1,7\% of TTA) 
in the late 1960s, 3) papal encyclics (maximum in 1980-83) and 4) "popular" theology (Tellado, Lafuente, Quoist, Bill Graham and 6 others) - almost 1\% of TTA in 1970-74.

In the field of social and political thought three major groups are distinct. The dominant influence is Marxist tradition with long-range oscillations: $1950 \mathrm{~s}-5,6 \%$ of TTA, $1960 \mathrm{~s}-4 \%, 1970 \mathrm{~s}-5,5 \%, 1980-83-4,4 \%$. The proportion of Marxist literature is slightly superior to that of Christian literature in all the periods, but in the 1960s. Anyhow the two traditions are the main ideological competitors leaving far behind other rivals: the Muslim and Indian traditions (with $0,2 \%$ of TTA each) and even the vague mystic-occult-spiritual field we have mentioned (1,3\% in the $1980 \mathrm{~s})$.

The "New Left" (Sartre, Marcuse, etc.) had its peak in 1965-69. Academic sociology (Fromm, Weber, Durkheim, Adorno, etc.) became stable in the 1970 s after a rapid growth.

There are very few big scientists in the 1,000 most translated authors: Darwin, Einstein, Gamow, Landau, Lorenz, Timoshenko (MDB - 1880). More books belong to popular scientists (Spock, Perel'man, G. Durrell, M. Gardner, Adamson and 15 others, MDB - 1911). Quite a new field is semiotics (Barthes, Chomsky, Foucault, LéviStrauss) with only 2 translations in 1955-59 and 193 in 1970-74 (MDB - 1919).

A separate group is composed of translated text books (it is seldom that they attain university level). Usually they have official status and are limited to one country — the USSR. This group made $0,1 \%$ of TTA in $1955-69,0,3 \%$ in $1970-74$, then followed a boom: $2,9 \%$ in $1975-79$ and $2,5 \%$ in $1980-83$.

The literature proper (fiction) may be divided into 3 categories: children's literature (including literature for adults, but read mostly by teenagers), popular literature and serious literature. Their contrasting fortunes are as follows (in per cent of TTA):

$\begin{array}{lrrrrrr} & 1955-59 & 1960-64 & 1965-69 & 1970-74 & 1975-79 & 1980-83 \\ \text { serious (424 authors) } & 46 & 44 & 40 & 36 & 31 & 32 \\ \text { popular (200 authors) } & 14 & 18 & 22 & 24 & 23 & 23 \\ \text { children's (113 authors) } & 16 & 14 & 14 & 13 & 18 & 18\end{array}$

Children's literature has a remarkable concentration of popularity among very few leading authors. The five leaders (Jules Verne, Enid Blyton, Walt Disney, Hans C. Andersen and the Grimm brothers) make up some $30 \%$ of all children's literature. On the whole children's literature is old (MDB - 1870), yet Russian and Swedish authors of the field are very young (MDB - 1904 and 1906). Swedish children's literature is exceptional in the fact that is mainly created by women ${ }^{4}$ (Lindgren, Lagerlöf, Jansson, Gripe, Sandberg, Beskow).

To the domain of popular literature we assign such genres as crime books, adventure books, science fiction, historical novels, horror literature, erotic literature. The proportion of this kind of literature grew very rapidly in the 1960s and after that remained constant. It is the youngest of the three major parts of fiction (MDB - 1903).

The oldest (MDB - 1886), but modest and ever declining part of popular literature is the historical novel $(0,6 \%$ of TTA, 10 authors: W. Scott, Sienkiewicz, Druon, L. Wallace, Fast and others). Almost as old (MDB - 1892), but a still expanding genre, is literature of adventure; it covered $4 \%$ of TTA about 1960 and almost $7 \%$ in the 1970s. Among the leading 50 authors many are well known to devotees around the world: Dumas (père), Maclean, Cartland, Slaughter, Konsalik, Z. Grey, DuMaurier, M. West, Robbins and many others.

Approximately half of popular literature is covered by the crime novel and story (10-12\% of TTA, 83 authors: Christie, Simenon, E. Gardner, E. Wallace, C. Brown, C. Doyle to mention only those that were published in translation more than a thousand 
times). A minor offshoot of this genre is the spy (or political crime) novel with a very sharp peak (1,6\% of TTA) in 1965-69 and ten names to its credit: J. Bruce, Le Carré, Fleming, Forsyth and others.

The youngest among the young are authors of science fiction (MDB - 1916). They are 36 in number: Asimov, H. G. Wells, Clarke, Lem, Bradbury, Boulle to name just a few. Science fiction contributed $1 \%$ of TTA in the 1950 s and almost $4 \%$ in the 1980 s. It is not only young, it is still growing. A curious niche of popular fiction is erotic literature with such leaders as H. Miller, J. Genet. The presence of de Sade and Cleland makes it very old (MDB - 1831). The proportion of this group grew 6 times and made $1 \%$ of TTA in 1980-83.

Popular literature as a whole is dominated by English-speaking authors $(80 \%)$, the closest rival - the group of French authors - is far below (some 10\%).

The last, but most honourable and the most numerous group of authors are those writers that create serious literature. Their MDB is 1881 (playwrights 1835 , poets 1846 , French 1856, German 1871, Russian 1875 and English 1894). The leaders among the poets (they are 35) are Puškin, Goethe, Majakovskij, Dante, Neruda, García Lorca, Rilke, Schiller, 'Omar Khayyam (if the Greek and Latin poets are added, Homer becomes the third and Vergilius - the sixth). With his average annual publication of 107 translations Shakespeare comes 6th in the general list of most translated authors just after Lenin (300), New Testament (156), Verne (146), Christie (135), Marx (112). The nearest rivals in drama are Brecht (26) and Molière (25). Then follow Ibsen, Strindberg, Shaw, Beckett, A. Ostrovskij, Dürrenmatt, Kalidasa (all 4 great Greek playwrights would join the last group if taken into account).

The list of 362 serious prosa-writers is headed by two Russians: L. Tolstoy (104 books a year) and Dostoevsky (85). P. Buck, Balzac, Hemingway, Čehov, Greene, Steinbeck, Cronin, Zola have more than 40 books annually.

The gradual decrease in the proportion of serious literature may be explained by the following model. Writers of serious literature often acquire a permanent ("classic") status in the cultural heritage of the world. This status ensures a constant rate of publications, the inherited part of serious literature seems numerically limited, some new names are ever joining the list and some leave it. The number of translated books outside the inherited core is not limited. Popular literature, children's literature, non-fiction are growing in size and the relative proportion of serious literature diminishes accordingly.

Most serious writers keep their numerical strength constant. We can mention some authors whose translations keep growing. In the 1955-59 period, the first translations of Ajtmatov, Gamzatov, Nabokov, Hailey, Salinger, Murdoch, Sagan, Calvino, García Márquez appeared. In the 1960s some new names were heard for the first time: Bellow, Grass, Borgès, Singer, Kishon. The post-humous fame (and the number of translated books) of such writers as Orwell, Hemingway, Fitzgerald, Joyce, Lawrence, SaintExupéry, Proust, Hesse, Gibran and going back in time - H. James, Wilde, Melville, Poe, Hoffmann is still growing. At the same time one observes a decrease in the number of translations of such former favourites as S. Lewis, Dreiser, Maugham, Mauriac, Rolland, Daudet, Maurois, Feuchtwanger, Erenburg. Some 15\% of "serious" writers go down and some $20 \%$ go up.

The last stage of our investigation was the statistical analysis of 300 most translated authors in their geographic distribution in 1975-79. To keep the parameters (authors) sufficiently distinct numerically the calculation of similarity between countries was somewhat modified. Now expression (2) was used: 


$$
\mathrm{S}_{\mathrm{AB}}=\frac{\sum \mathrm{d}_{\mathrm{i}} \cdot \mathrm{p}_{\mathrm{i}}(\mathrm{min})}{\sqrt{\sum \mathrm{d}_{\mathrm{i}} \cdot \mathrm{p}(\mathrm{A}) \cdot \sum \mathrm{d}_{\mathrm{i}} \cdot \mathrm{p}(\mathrm{B})}}
$$

where $d_{i}^{\prime}=\ln \left(p_{\max }\right)-\ln \left(\vec{p}_{i}+1\left(\vec{p}_{\max }\right.\right.$ is the proportion of the most frequent parameter).

The change of term $d$ for $d$ ' will make it 1 for the most popular author; all other authors will have their d' considerably greater.

The results of clustering are represented in Fig. 6 , the double lines denote $S \geq 60$, single lines $S=54-59$ and dotted lines $S=48-53$. The problem of linguistic comparability was solved in the following way: while calculating $S$ for a pair of countries all authors with the national languages of both countries were excluded.

In Fig. 6 we see a central cluster of large countries, East European and North European clusters.

The North European cluster may be termed "popular." The proportion of nonfiction is very low here $(5 \%)$, yet the proportion of popular science is equal to the average world level. Inside fiction this cluster has the lowest proportion of "serious" literature $(21 \%)$ and the highest proportion of "popular" literature (46\%) (mostly literature of crime and adventure).

The East European cluster has a high proportion of non-fiction (26\%) which mostly consists of books by official leaders and Marxist literature. The cluster is very "serious": the proportion of popular literature is very low (13\%), only the proportion of science fiction is comparable to the world average. Parareligious literature was not published in 1975-79 in the countries of the cluster (with the single exception of Yugoslavia).

Serious literature makes up $64 \%$ of all fiction. Poetry stands rather high (some $9 \%$ of all "serious" literature). The same tendencies are seen in the USSR: non-fiction attains $69 \%$, to the official leaders' books and Marxist literature' school textbooks are added. It is due to the abnormal development of non-fiction, and especially to textbooks, that the USSR does not join the East European cluster.

A country may be characterized by a number of positive and negative markers (authors). The quantitative value of such markers will be calculated according to the expression

$$
Q_{x}=\frac{F-M}{\sqrt{m+i}}
$$

where $\mathrm{F}$ - absolute value of the parameter in country $\mathrm{X}$ (i.e. number of books by an author published in country);

$\mathrm{m}$ - N.p ( $\mathrm{N}$ being the world total of the translated books by an author, and $\mathrm{p}$ the share of country $X$ in the world total of all translated books).

A few examples will show that sometimes the positive markers give a certain general impression of the country's preferences. We shall give ten authors with highest $\mathrm{Q}$ and some other authors (with their rank in brackets).

Poland. Čtvrtek (a Czech writer for children), Shakespeare, F. Clifford, Simonov, St. Augustin, Cortázar, Conrad, Jansson, Polevoj, Barclay. Poland certainly follows Christian tradition: Augustine, New Testament (11), L. Boros (14), Paul VI (16). In fiction it leans towards authors treating serious moral issues: Conrad, Trifonov (17), Dostoevsky (20), H. Bazin (21). 
Czechoslovakia. Leonov, Waltari, Simonov, Aldridge, Kataev, Gajdar, Remarque, Shakespeare, France, Polevoj. In 1975-79 it was a typical communist country with the list of positive markers dominated by Russian authors: Leonov, Kataev, Gajdar, N. Nekrasov (13), Šolohov (14), Č hov (16), A. Tolstoy (18), Lermontov (24), Pushkin (26), Turgenev (30). We should mention war novels of Simonov, Polevoj, Bykov (12) and such anti-nazi authors as Brecht (15), Feuchtwanger (19), Seghers (21).

Italy. Delly, Schulz, Freud, Rahner, Stendhal, Nietzsche, Adorno, Cronin, E. Caldwell, Alcott. Most great European countries defy attempts to find one or two major themes. Italy is one of them. However, psychology should be noted: Freud, Jung (12), J. Dewey (23). There are 4 poets in the list of 30 authors: Petrarca (15), Apollinaire (16), Goethe (24), T. S. Eliot (26).

Spain. Perrault, Grimm, Salgari, Verne, Spyri, Alcott, De Amicis,/Stratemeyer production/, L. Werner, D'Ami. Spain is the leader in the field of children's literature ( $30 \%$ of the world total). Yet the translations of modern Scandinavian writers for children are very few.

Brazil. Lafuente, Darlton, Tellado, Cartland, Mahr, Lobsang Rampa, Scheer, Piaget, Hesse, Peale. There are distinct spheres where specific translations of Brazil are concentrated. Adventure: Darlton, Cartland, Mahr, Linares (11), Robbins (15), M. West (16); popular philosophy and psychology: Peale, Durant (20), Russell (24) and religion (especially mystic and exotic): Lafuente, Tellado, Lobsang, Krishnamurti (12), Castañeda (17).

Argentina. Lobsang Rampa, Amado, Blavatsky, Brunton, Krishnamurti, Sartre, E. White, Bradbury, Tagore, Fatio. The translations of this country are colored in spiritual and oriental hues: Lobsang, Blavatsky, Brunton, Krishnamurti, Tagore, Sivananda (16).

Korea. Fromm, Galbraith, Sagan, Drucker, Hesse, Jong, Sheldon, Hemingway, Gibran, Russell. The prevailing feature of Korea (Erica Jong notwithstanding) is seriousness, reflected in such groups as sociology and economics: Fromm, Galbraith, Drucker; philosophy: Russell, Kierkegaard (23), Hegel (26); popular psychology: Carnegie (12), Peale (17); serious (often lyrical) fiction: Hesse, Hemingway, Buck (11), Saint-Exupéry (20), R. Bach (23), Dostoevsky (24).

Turkey. Cartland, al-Ghazzali, Stalin, Lenin, Gor'kij, J. London, Dimitrov, Mao Tse-tung, Steinbeck, Hoxha. The Turkey of 1975-79 (just before the military coup of 1980) was the playground of conflicting ideologies with Islamic al-Ghazzali on the one hand, and diverse communist authors on the other: Stalin, Lenin, Dimitrov, Mao, Hoxha, Marx (11), Engels (13), "Che" Guevara (18). In fiction' literature of adventure (both for adults and young) is predominant: Cartland, London, Robbins (15), Spyri (20), Stevenson 21, Guillot (23), Kipling (27), Verne (28), Defoe (30).

In the same way positive and negative markers may be calculated for groups of countries. To reduce chance extreme oscillations it is useful to omit the data of one country in order to minimize the group sum in the case of positive markers and to maximize it for negative markers. For example, for a group of East Europeen countries the list of most specific authors includes: Kataev, Simonov, A. Tolstoy, Carpentier, Zola, Balzac, Polevoj, Čapek, Pushkin, Sholohov, which resembles the Czechoslovakian list very much. The Russian authors make up 12 out of 30 leading specific writers, to this number a few East European authors are added: Čapek, Karalijčev (11), Jókai (14), Sienkiewicz (21), Iwaszkiewicz (22), Sadoveanu (23). Thus the cluster seems very selfcentred (if Russia is tacitly included here). Among external influences some Spanishlanguage authors may be noted: Carpentier, Asturias (27), García Lorca (28), García Márquez (30). 
The negative markers of the group are mostly world writers of popular literature and literature for children: Blyton, /Stratemeyer production/, /Disney production/, Cartland, Goscinny, C. Brown, Maclean, Simenon, E. Wallace, N. Carter, Makaryčev, Mao. The same negative markers will be found in the USSR list which differs only at the beginning. The Soviet list was headed by Agatha Christie, the New Testament, /Disney/ came the third and the Old Testament the fourth. 5

The foregoing investigation was mostly aimed at learning basic facts. The data clearly demonstrate the diversity of translation practices of various countries. Some of these differences are persistent (linguistic spectra), others change with time. With the exception of a few countries (the USSR and Albania among them) the diversity is diminishing, the thematic clusters are coalescing. These are hopeful signs of cultural convergence going on in the world.

The present fact-finding study is, however, inconclusive as far as causal relations are concerned. It poses new problems. What are the causes and effects behind the statistical correlations discovered? The political situation explains much in all spheres of publication activity of communist countries. It is clearly the major factor behind the authors translated in Turkey, but it has very little to do with translations in Western Europe. Were economic factors (e.g. the provisions of the Berne convention) responsible for the growing cultural isolation of the USSR after 1974? Is it the accessibility of English that explains the "popular" character of Scandinavian translation activity or is it some inner psycho-social drive to which may be attributed this peculiar preference of North European readers? These and other questions should be answered by further studies.

Notes

1. In UNESCO publications the corresponding statistical tables are inappropriately called Translation of books. Let us stress the fact that all statistical data refer to the publication of translated books. The time of the translation itself does not always coincide with the year of publication, some translations published are decades and even centuries old.

2. We use the transcription of Index Translationum which follows the recommendations of ISO.

3. The MDB becomes nonsense when ancient authors are included. To be on the realistic side we calculated the measure omitting all authors born before 1400 .

4. There are 137 women (MDB - 1899) among the 1,000 most translated authors, their contribution to the whole sum is ever growing (9\% of TTA in 1955-59 and $13 \%$ in $1980-83$ ).

5. To be sure, positive and negative markers change with time. The five latest weekly issues of the Soviet book review Knizhnoye Obozrenie (summer of 1990) list 184 translated books, many of them are negative markers of 1975-79: E. Burroughs, Carnegie, J. Chase, Fromm, Kirst, Nietzsche, Pasternak, M. West. Agatha Christie has 5 publications, as many as in the whole $1975-79$ period.

\section{TABLE 1 \\ AVERAGE ANNUAL PUBLICATION OF TRANSLATED BOOKS (Number of titles)}

$\begin{array}{llllll}1955-59 & 1960-64 & 1965-69 & 1970-74 & 1975-79 & 1980-83\end{array}$

$\begin{array}{lrrrrrr}\text { TOTAL } & 28,000 & 34,000 & 38,000 & 45,000 & 52,000 & 54,000 \\ \text { United Kingdom } & 680 & 660 & 720 & 860 & 1,650 & 1,150 \\ \text { Iceland } & 120 & 120 & 150 & 160 & 160 & 250 \\ \text { Norway } & 640 & 720 & 840 & 1,150 & 1,000 & 1,050 \\ \text { Denmark } & 560 & 800 & 1,200 & 1,550 & 1,900 & 1,500 \\ \text { Sweden } & 920 & 1,150 & 1,450 & 1,500 & 1,450 & 1,800\end{array}$




\begin{tabular}{|c|c|c|c|c|c|c|}
\hline Finland & 520 & 640 & 740 & 900 & 900 & 1,400 \\
\hline Netherlands & 1,150 & 1,750 & 1,900 & 1,800 & 2,650 & no data \\
\hline Belgium & 800 & 940 & 980 & 820 & 760 & 96 \\
\hline France & 1,400 & 1,650 & 1,900 & 2,100 & 3,450 & 2,95 \\
\hline Portugal & 640 & 700 & 820 & 640 & 500 & 66 \\
\hline Spain & 1,000 & 1,550 & 2,400 & 3,500 & 5,250 & 6,65 \\
\hline Italy & 1,250 & 1,450 & 2,100 & 1,950 & 1,950 & 2,20 \\
\hline Greece & 220 & 170 & no data & 360 & 300 & 48 \\
\hline Switzerland & 540 & 800 & 740 & 920 & 920 & \\
\hline Austria & 170 & 180 & 280 & 460 & 360 & 40 \\
\hline Germany, Federal Rep. & 1,550 & 2,650 & 2,800 & 4,950 & 6,300 & 6,60 \\
\hline German Democratic Rep. & 470 & 500 & 350 & 650 & 880 & 84 \\
\hline Poland & 900 & 740 & 840 & 900 & 1,100 & 8 \\
\hline Czechoslovakia & 1,400 & 1,750 & 1,700 & 1,400 & 1,400 & 1,20 \\
\hline Hungary & 360 & 580 & 920 & 1,050 & 1,250 & 1,05 \\
\hline Romania & 880 & 800 & 840 & 780 & 700 & 60 \\
\hline Bulgaria & 520 & 580 & 580 & 420 & 580 & 72 \\
\hline Yugoslavia & 820 & 1,200 & 1,500 & 1,300 & 1,250 & 1,30 \\
\hline Albania & 75 & 120 & 120 & 80 & 110 & 12 \\
\hline USSR & 4,650 & 4,750 & 3,750 & 4,300 & 6,950 & 7,25 \\
\hline Turkey & 480 & 520 & 720 & 980 & 900 & 80 \\
\hline Syria & no data & no data & 25 & 35 & 50 & \\
\hline Lebanon & no data & no data & 60 & 70 & no data & \\
\hline Israel & 500 & 580 & 460 & 340 & 280 & 32 \\
\hline Iran & 60 & 140 & no data & 180 & no data & no da \\
\hline Pakistan & 75 & 140 & 180 & 50 & 60 & \\
\hline India & 600 & 880 & 880 & 740 & 640 & 68 \\
\hline Sri Lanka & 60 & 80 & 85 & 50 & 50 & \\
\hline Burma & no data & 30 & 100 & 60 & 70 & no da \\
\hline Thailand & no data & no data & no data & 55 & 35 & \\
\hline Malaysia & no data & no data & 25 & 35 & 120 & \\
\hline Indonesia & 65 & 60 & 60 & 65 & 280 & 1 \\
\hline Taiwan & 160 & 100 & 200 & no data & no data & no da \\
\hline Korea, Rep. of & 190 & 220 & 170 & 150 & 220 & 4 \\
\hline Japan & 1,300 & 950 & 1,80 & 2,250 & 2,450 & 2,4 \\
\hline Australia & no data & no data & 15 & 40 & 65 & \\
\hline Egypt & 180 & 310 & 280 & 160 & 140 & 1 \\
\hline South African Rep. & 20 & 100 & 150 & no data & no data & no dz \\
\hline Canada & 20 & 85 & 110 & 140 & 330 & \\
\hline United States & 880 & 1,450 & 2,100 & 2,200 & 1,700 & 1,2 \\
\hline Mexico & 100 & 410 & 330 & 210 & 150 & no da \\
\hline Colombia & no data & no data & 25 & 15 & 80 & \\
\hline Brazil & 450 & 420 & 500 & 920 & 1,00 & \\
\hline Argentina & 310 & 340 & 390 & 280 & 330 & \\
\hline
\end{tabular}


TABLE 2

WORLD LINGUISTIC SPECTRUM (1960-1983)

\begin{tabular}{cccccc}
$\begin{array}{c}\text { Original } \\
\text { language }\end{array}$ & $\begin{array}{c}\text { Proportion } \\
\text { of the } \\
\text { world's } \\
\text { total }\end{array}$ & $\begin{array}{c}\text { Same } \\
\text { outside } \\
\text { own } \\
\text { borders }\end{array}$ & $\begin{array}{c}\text { Original } \\
\text { language }\end{array}$ & $\begin{array}{c}\text { Proportion } \\
\text { of the } \\
\text { world's } \\
\text { total }\end{array}$ & $\begin{array}{c}\text { Same } \\
\text { outside } \\
\text { own } \\
\text { borders }\end{array}$ \\
\hline
\end{tabular}

(1)

English

French

Russian

German

Italian

Swedish

Spanish

Czech

Hungarian

Danish

Polish

Classical Greek

Latin

Serbo-Croatian

Dutch

Romanian

Norwegian

Bulgarian

Hebrew

Arabic
(2)

392

123

118

96

26

20

17

16

13

12

11

11

10

9,8

9,0

9,0

6,2

5,3

5,3

4,2
(3)

(1)

Chinese

Japanese

78

Ukrainian

Sanskrit

Slovak

Portuguese

Bengali

Finnish

Georgian

Estonian

8,5

Byelorussian

Lithuanian

Modern Greek

1,9

2,0

2,6

4,0

Latvian

Albanian

Hindi

Persian

Armenian

Yiddish

(2)

(3)

3,8

3,6

3,6

3,5

0,7

3,2

1,1

Slovenian

2,7

Turkish

2,2

2,1

1,6

1,6

1,6

1,5

1,5

1,4

1,4

1,4

1,3

1,2

1,2

1,1

1,1

1,4

0,6

1,6

0,15

0,3

0,2

0,3

0,2

0,1

0,4

0,2

1,0

0,3

\section{TABLE 3}

LINGUISTIC SPECTRA OF MAJOR U.D.C. HEADINGS (1960-83)

$\begin{array}{lllllllll}1 & 2 & 3 & 5 & 6 & 7 & 8 & 9\end{array}$

Philo- Reli- Social Pure Applied Arts ${ }^{5}$ Lite- History

sophy ${ }^{1}$ gion $^{2}$ Sciences $^{3}$ Science Sciences ${ }^{4}$ rature $^{6}$ geography

\begin{tabular}{lrrrrrrrr}
\hline Czech & 3 & 3 & 20 & 37 & 41 & 21 & 11 & 16 \\
Danish & 9 & 5 & 4 & 10 & 12 & 12 & 14 & 11 \\
Dutch & 7 & 25 & 5 & 8 & 14 & 18 & 7 & 9 \\
English & 373 & 261 & 276 & 430 & 388 & 286 & 451 & 334 \\
French & 170 & 183 & 102 & 74 & 88 & 180 & 120 & 122 \\
German & 170 & 144 & 90 & 93 & 132 & 145 & 66 & 113 \\
Greek, Cl. & 32 & 74 & 2 & 2 & 1 & 1 & 8 & 8 \\
Hebrew & 1 & 50 & 5 & 1 & - & 3 & 1 & 6 \\
Hungarian & 3 & 2 & 14 & 22 & 17 & 34 & 9 & 15 \\
ltalian & 17 & 39 & 19 & 20 & 20 & 80 & 23 & 27 \\
Latin & 22 & 58 & 4 & 4 & 3 & 3 & 6 & 17
\end{tabular}




\begin{tabular}{|c|c|c|c|c|c|c|c|c|}
\hline Polish & 5 & 4 & 13 & 10 & 13 & 13 & 11 & 13 \\
\hline Romanian & 2 & 1 & 20 & 10 & 11 & 14 & 6 & 12 \\
\hline Russian & 102 & 15 & 265 & 241 & 141 & 74 & 87 & 108 \\
\hline Serbo- & & & & & & & & \\
\hline Croatian & 1 & 一 & 43 & 5 & 5 & 10 & 5 & 12 \\
\hline Spanish & 7 & 17 & 12 & 5 & 4 & 14 & 24 & 17 \\
\hline Swedish & 8 & 12 & 10 & 11 & 23 & 17 & 25 & 15 \\
\hline $\begin{array}{ll}\text { 1. } & \text { Sanskrit } 1 \\
\text { 2. } & \text { Hebrew 5 } \\
\text { 3. } & \text { Chinese } 7 \\
\text { 4. } & \text { Slovak 6; } \\
\text { 5. } & \text { Japanese } \\
\text { 6. } & \text { Norwegia } \\
\text { 7. } & \text { Norwegia }\end{array}$ & $\begin{array}{l}0, \text { Chi } \\
0, \text { Ara } \\
\text { (only }\end{array}$ & $\begin{array}{l}\text { Sanskr } \\
30-83)\end{array}$ & $\begin{array}{l}\text {, Norw } \\
\text { banian } 8\end{array}$ & $\begin{array}{l}\text { 8, Por } \\
\text { garian }\end{array}$ & se $5, U_{1}$ & 5 & & \\
\hline
\end{tabular}

TABLE 4

LINGUISTIC SPECTRA (1960-83)

\begin{tabular}{lrrrrrrrrrrr} 
& \multicolumn{1}{c}{$\mathbf{E}$} & $\mathbf{F}$ & $\mathbf{R}$ & $\mathbf{G}$ & $\mathbf{S c}$ & $\mathbf{S p}$ & $\mathbf{I t}$ & $\mathbf{C l}$ & $\mathbf{A r}$ & $\mathbf{J}$ & $\mathbf{C h}$ \\
\hline United Kingdom & 31 & 278 & 76 & 234 & 57 & 24 & 78 & 32 & 10 & 12 & 5 \\
Iceland & 522 & 53 & 9 & 49 & 184 & 3 & 3 & 4 & 1 & & 2 \\
Norway & 665 & 36 & 8 & 52 & 189 & 5 & 6 & 4 & 1 & 1 & 1 \\
Denmark & 541 & 84 & 14 & 99 & 189 & 9 & 10 & 12 & 2 & 2 & 4 \\
Sweden & 615 & 69 & 16 & 90 & 106 & 8 & 8 & 6 & 1 & 1 & 2 \\
Finland & 565 & 62 & 30 & 89 & 205 & 7 & 10 & 5 & 1 & 3 & 1 \\
Netherlands & 566 & 104 & 18 & 197 & 34 & 8 & 15 & 17 & 3 & 3 & 3 \\
Belgium & 526 & 131 & 8 & 164 & 17 & 10 & 20 & 21 & 2 & 2 & - \\
France & 565 & 23 & 43 & 129 & 18 & 29 & 55 & 39 & 5 & 4 & 4 \\
Portugal & 280 & 264 & 22 & 57 & 7 & 220 & 40 & 6 & 1 & 2 & - \\
Spain & 428 & 249 & 20 & 112 & 13 & - & 68 & 22 & 5 & 1 & 2 \\
Italy & 419 & 238 & 32 & 139 & 10 & 26 & 12 & 45 & 1 & 2 & 3 \\
Greece & 504 & 244 & 62 & 99 & 12 & 13 & 42 & 4 & 3 & 1 & 2 \\
Switzerland & 495 & 185 & 30 & 128 & 26 & 10 & 41 & 21 & 2 & 2 & 2 \\
Austria & 569 & 195 & 27 & 31 & 46 & 8 & 27 & 13 & 3 & 2 & 1 \\
FRG & 633 & 121 & 29 & 37 & 39 & 24 & 29 & 25 & 2 & 3 & 4 \\
GDR & 137 & 84 & 384 & 6 & 29 & 25 & 20 & 28 & 4 & 3 & 4 \\
Poland & 230 & 100 & 200 & 104 & 25 & 19 & 20 & 23 & 2 & 2 & 1 \\
Czechoslovakia & 149 & 96 & 250 & 118 & 19 & 17 & 25 & 11 & 1 & 2 & 1 \\
Hungary & 112 & 68 & 135 & 96 & 8 & 11 & 16 & 14 & 1 & 2 & 1 \\
Romania & 86 & 103 & 130 & 55 & 6 & 18 & 24 & 14 & 2 & 2 & 1 \\
Bulgaria & 82 & 53 & 422 & 66 & 6 & 22 & 14 & 8 & 1 & 2 & 1 \\
Yugoslavia & 208 & 103 & 97 & 112 & 17 & 12 & 33 & 13 & 3 & 2 & 2 \\
Albania & 69 & 66 & 270 & 54 & 11 & 10 & 19 & 8 & - & 3 & 10 \\
USSR & 100 & 29 & 505 & 43 & 8 & 9 & 5 & 3 & 2 & 2 & 2 \\
Turkey & 376 & 198 & 63 & 90 & 13 & 12 & 17 & 11 & 72 & 2 & 6 \\
Israel & 409 & 72 & 119 & 73 & 8 & 5 & 11 & 12 & 11 & 2 & 2 \\
India & 395 & 22 & 57 & 19 & 5 & 2 & 4 & 8 & 9 & 1 & 3 \\
Indonesia & 505 & 28 & 40 & 25 & 3 & 3 & 3 & 5 & 18 & 6 & 4 \\
Taiwan & 759 & 83 & 22 & 41 & 5 & 5 & 13 & 19 & - & no data & -
\end{tabular}




$\begin{array}{lrrrrrrrrrrr}\text { Korea } & 686 & 89 & 16 & 91 & 6 & 3 & 6 & 3 & 1 & 14 & - \\ \text { Japan } & 637 & 123 & 57 & 105 & 10 & 7 & 12 & 6 & 1 & - & 6 \\ \text { Egypt } & 685 & 77 & 44 & 43 & 4 & 3 & 6 & 14 & 1 & - & 3 \\ \text { South Africa } & 426 & 93 & 7 & 228 & 74 & 21 & 27 & 14 & \text { no data } & - \\ \text { Canada } & 618 & 142 & 18 & 59 & 6 & 13 & 28 & 39 & 3 & 1 & 2 \\ \text { United States } & 10 & 246 & 134 & 245 & 46 & 47 & 51 & 61 & 12 & 36 & 21 \\ \text { Mexico } & 718 & 86 & 12 & 72 & 1 & 3 & 28 & 34 & - & 1 & - \\ \text { Brazil } & 548 & 147 & 10 & 67 & 4 & 101 & 26 & 8 & 2 & 1 & 1 \\ \text { Argentina } & 569 & 207 & 8 & 107 & 6 & 1 & 33 & 26 & 2 & 2 & 2\end{array}$

E - English, F - French, R - Russian, G - German, Sc - Scandinavian (Danish, Norwegian, Swedish), $\mathrm{Sp}$ - Spanish, It - Italian, Cl - Classical (Cl. Greek, Latin), Ar - Arabic, J - Japanese, Ch - Chinese.

TABLE 5

WORLD THEMATIC SPECTRUM

U.D.C. Headings $\quad 1955-59 \quad 1960-64 \quad 1965-69 \quad 1970-74 \quad 1975-59 \quad 1980-83$

\begin{tabular}{lrrrrrr}
\hline 1. Philosophy & 33 & 38 & 44 & 50 & 50 & 51 \\
2. Religion & 57 & 67 & 69 & 59 & 56 & 58 \\
3. Social Sciences & 103 & 103 & 109 & 130 & 136 & 110 \\
5. Pure Science & 45 & 54 & 64 & 64 & 68 & 55 \\
6. Applied Sciences & 85 & 81 & 83 & 87 & 89 & 94 \\
7. Arts & 35 & 37 & 44 & 50 & 56 & 55 \\
8. Literature & 546 & 533 & 498 & 480 & 464 & 503 \\
9. History, geography & 96 & 87 & 89 & 80 & 79 & 73
\end{tabular}

TABLE 6

THEMATIC SPECTRA (1955-1983)

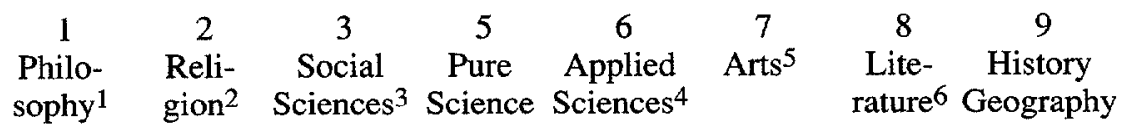

\begin{tabular}{lrrrrrrrr}
\hline United & & & & & & & & \\
$\quad$ Kingdom & 34 & 121 & 92 & 85 & 74 & 109 & 360 & 118 \\
Iceland & 20 & 39 & 34 & 19 & 34 & 21 & 740 & 90 \\
Norway & 17 & 43 & 36 & 25 & 51 & 28 & 730 & 68 \\
Denmark & 31 & 44 & 57 & 32 & 59 & 34 & 660 & 79 \\
Sweden & 24 & 42 & 44 & 36 & 63 & 35 & 676 & 74 \\
Finland & 33 & 78 & 46 & 28 & 78 & 31 & 633 & 67 \\
Netherlands & 50 & 59 & 59 & 52 & 80 & 42 & 566 & 88 \\
Belgium & 44 & 73 & 49 & 48 & 84 & 53 & 583 & 58 \\
France & 50 & 71 & 71 & 51 & 64 & 60 & 524 & 105 \\
Portugal & 55 & 59 & 79 & 16 & 42 & 24 & 665 & 55 \\
Spain & 64 & 90 & 101 & 50 & 133 & 54 & 425 & 75 \\
Italy & 75 & 104 & 118 & 42 & 77 & 58 & 416 & 105 \\
Greece & 67 & 38 & 128 & 20 & 53 & 29 & 557 & 101 \\
Switzerland & 46 & 100 & 59 & 41 & 68 & 91 & 476 & 115
\end{tabular}




$\begin{array}{lrrrrrrrr}\text { Austria } & 27 & 77 & 50 & 42 & 46 & 37 & 619 & 99 \\ \text { FRG } & 44 & 69 & 63 & 47 & 53 & 60 & 581 & 79 \\ \text { GDR } & 28 & 16 & 126 & 83 & 65 & 46 & 566 & 63 \\ \text { Poland } & 26 & 45 & 130 & 102 & 140 & 42 & 435 & 69 \\ \text { Czecho- } & & & & & & & & \\ \quad \text { slovakia } & 22 & 7 & 131 & 85 & 136 & 46 & 497 & 67 \\ \text { Hungary } & 19 & 10 & 138 & 89 & 128 & 92 & 428 & 77 \\ \text { Romania } & 19 & 6 & 195 & 63 & 180 & 73 & 389 & 68 \\ \text { Bulgaria } & 24 & 6 & 178 & 69 & 157 & 49 & 437 & 73 \\ \text { Yugoslavia } & 26 & 30 & 226 & 33 & 58 & 48 & 511 & 60 \\ \text { Albania } & - & 4 & 443 & 48 & 19 & 12 & 424 & 43 \\ \text { USSR } & 33 & 5 & 276 & 98 & 99 & 21 & 398 & 66 \\ \text { USSR } & 33 & 5 & 209 & 98 & 99 & 21 & 465 & 66 \\ \text { Turkey } & 36 & 63 & 145 & 34 & 90 & 16 & 559 & 41 \\ \text { Israel } & 24 & 62 & 113 & 61 & 63 & 28 & 501 & 141 \\ \text { Iran } & 80 & 49 & 117 & 69 & 65 & 23 & 408 & 174 \\ \text { Pakistan } & 67 & 221 & 128 & 78 & 58 & 6 & 266 & 171 \\ \text { India } & 54 & 144 & 114 & 42 & 43 & 12 & 451 & 136 \\ \text { Sri Lanka } & 20 & 148 & 136 & 130 & 44 & 4 & 364 & 153 \\ \text { Burma } & 23 & 39 & 78 & 46 & 54 & 21 & 522 & 213 \\ \text { Indonesia } & 66 & 134 & 159 & 60 & 123 & 15 & 367 & 68 \\ \text { Taiwan } & 52 & 71 & 133 & 132 & 106 & 32 & 359 & 106 \\ \text { Korea } & 108 & 186 & 157 & 29 & 40 & 47 & 357 & 68 \\ \text { Japan } & 64 & 32 & 169 & 94 & 105 & 59 & 396 & 74 \\ \text { Egypt } & 78 & 72 & 204 & 79 & 70 & 38 & 339 & 110 \\ \text { South Africa } & 9 & 88 & 18 & 34 & 34 & 9 & 760 & 47 \\ \text { Canada } & 80 & 141 & 152 & 53 & 140 & 60 & 252 & 108 \\ \text { United } & & & & & & & & \\ \quad \text { States } & 55 & 144 & 99 & 96 & 75 & 109 & 276 & 142 \\ \text { Mexico } & 74 & 42 & 197 & 100 & 262 & 32 & 218 & 68 \\ \text { Brazil } & 109 & 73 & 132 & 46 & 90 & 17 & 456 & 68 \\ \text { Argentina } & 230 & 60 & 160 & 35 & 96 & 41 & 317 & 56 \\ & & & & & & & & \end{array}$

TABLE 7

THEMATIC EVOLUTION IN SELECTED REGIONS

$\begin{array}{llllll}1955-59 & 1960-64 & 1965-69 & 1970-74 & 1975-79 & 1980-83\end{array}$

\begin{tabular}{|c|c|c|c|c|c|c|}
\hline \multicolumn{7}{|l|}{ Philosophy } \\
\hline Latin America & 94 & 130 & 143 & 127 & 177 & 126 \\
\hline Mediterranean countries & 38 & 40 & 53 & 68 & 66 & 74 \\
\hline FRG, Austria, Switzerland & 34 & 35 & 39 & 36 & 46 & 57 \\
\hline Other countries & 29 & 34 & 39 & 46 & 42 & 42 \\
\hline \multicolumn{7}{|l|}{ Religion } \\
\hline Middle East & 63 & 94 & 102 & 109 & 116 & 134 \\
\hline Indian subcontinent & 63 & 95 & 106 & 111 & 123 & 137 \\
\hline Poland & 19 & 33 & 47 & 49 & 47 & 72 \\
\hline GDR & 7 & 7 & 3 & 16 & 19 & 32 \\
\hline Yugoslavia & 10 & 13 & 23 & 46 & 33 & 47 \\
\hline
\end{tabular}


France, Belgium,

Portugal, Spain

North America

Other countries
106

146
53

\section{Social Sciences}

Western Europe

America

Eastern Europe

(GDR, Czechoslovaki

Poland, Hungary,

Romania, Bulgaria)

USSR

170

Pure Science

GDR, Poland,

Czechoslovakia

Balkans

USSR

Other countries

Western Europe

America

Japan

Eastern Europe

(incl. USSR)

98
172
46

42

83

182

44

105

156

104

60

55

31

100

52

69

45

48

58

45

105

154

131
Applied Sciences

122

140

108
140

83

59

122

60

52

46

49

140

51

67

$90 \quad 107$

139

154

104

146

126

176

151

204

256

255

96

49

89

59

$\begin{array}{rrr}84 & 79 & 58 \\ 50 & 39 & 37 \\ 83 & 134 & 126 \\ 60 & 57 & 44\end{array}$

87

65

103

78

$91 \quad 94$

107

113

94
107

102

107

82

95

99

149

73

History, Geography

America

156

200

119

120

110

135

109

96

84

49

81

Other countries

86

81

78

77

TABLE 8

500 MOST TRANSLATED AUTHORS

(Annual number of books published)

\begin{tabular}{lrrrlrrr} 
& 1955 & 1965 & 1975 & & 1955 & 1965 & 1975 \\
& 1964 & 1974 & 1983 & & 1964 & 1974 & 1983 \\
\hline Aarons & 6 & 21 & 3 & Anouilh & 7 & 9 & 4 \\
Aeschyllus & 14 & 13 & 13 & (Arabian Nights) & 28 & 30 & 52 \\
Aesopus & 6 & 9 & 14 & Aragon & 11 & 8 & 6 \\
Ajtmatov & 8 & 18 & 26 & Aristophanes & 12 & 10 & 10 \\
Alcott & 18 & 26 & 26 & Aristotle & 19 & 26 & 23 \\
Amado & 7 & 8 & 18 & Arthur R. & & 11 & 19 \\
Ambler & 6 & 13 & 10 & Asimov & 8 & 34 & 66 \\
Andersen H. C. & 60 & 70 & 112 & Asturias & 4 & 14 & 8 \\
Anderson P. & 2 & 8 & 12 & Augustin & 18 & 15 & 13 \\
Andrić & 14 & 9 & 10 & Aurobindo & 5 & 10 & 8
\end{tabular}




\begin{tabular}{|c|c|c|c|c|c|c|c|}
\hline Austen J. & 8 & 8 & 11 & Ceausescu & - & 36 & 47 \\
\hline Bagley & - & 14 & 22 & Chehov & 64 & 53 & 49 \\
\hline Baldwin J. & 4 & 14 & 10 & Cervantes & 22 & 20 & 20 \\
\hline Ballard W. T. & 9 & 16 & 15 & Cesco & 3 & 9 & 12 \\
\hline Balzac & 66 & 64 & 52 & Chandler & 8 & 12 & 17 \\
\hline Barth K. & 10 & 10 & 6 & Charles T. & 4 & 7 & 8 \\
\hline Baudelaire & 10 & 11 & 17 & Charteris & 18 & 24 & 9 \\
\hline Baum V. & 16 & 12 & 10 & Chase J. H. & 16 & 49 & 29 \\
\hline Beauvoir & 11 & 30 & 26 & Chatterji S. & 15 & 6 & 5 \\
\hline Beckett & 8 & 20 & 14 & Chesterton & 18 & 8 & 16 \\
\hline Bellow & 2 & 11 & 16 & Cheyney & 29 & 15 & 7 \\
\hline Benzoni & 1 & 13 & 17 & Chisholm & 1 & 10 & 9 \\
\hline (Bhagavadgita) & 12 & 11 & 13 & Christie A. & 85 & 108 & 219 \\
\hline Bianki & 11 & 7 & 8 & Cicero & 18 & 22 & 18 \\
\hline (Bible, N.T.) & 140 & 145 & 176 & Clarke A. & 7 & 13 & 24 \\
\hline (Bible, O.T.) & 64 & 94 & 130 & Colette & 24 & 13 & 14 \\
\hline Blyton & 72 & 117 & 145 & Collins W. & 6 & 7 & 7 \\
\hline Boccaccio & 11 & 16 & 15 & Collodi & 13 & 14 & 24 \\
\hline Böll & 13 & 28 & 26 & Conrad & 15 & 17 & 25 \\
\hline Boileau P. & 6 & 7 & 14 & Cookson C. & 3 & 5 & 26 \\
\hline Bond $\mathrm{M}$. & 1 & 9 & 19 & Cooper J. F. & 29 & 29 & 34 \\
\hline Borges & 3 & 13 & 18 & Courths-Mahler & 6 & 20 & 7 \\
\hline Boulle P. & 10 & 9 & 5 & Cousteau & 3 & 7 & 13 \\
\hline Bradbury & 7 & 13 & 18 & Creasey & 25 & 24 & 5 \\
\hline Brand $\mathrm{M}$. & 7 & 22 & 13 & Crichton & & 9 & 10 \\
\hline Brecht & 21 & 29 & 27 & Cronin & 48 & 46 & 37 \\
\hline Brežnev & 3 & 68 & 142 & C̆ukovskij & 14 & 9 & 15 \\
\hline Bristow & 4 & 10 & 9 & Curtiss U. & 5 & 8 & 8 \\
\hline Bromfield & 21 & 10 & 8 & Curwood & 13 & 9 & 12 \\
\hline Brontë Ch. & 12 & 16 & 12 & von Däniken & & 9 & 17 \\
\hline Brontë E. & 11 & 14 & 10 & Dahl R. & 3 & 6 & 20 \\
\hline Brown $\mathrm{C}$. & 37 & 51 & 29 & Dailey J. & & & 25 \\
\hline Brown F. & 6 & 8 & 7 & D'Ami & & 6 & 18 \\
\hline Bruce J. & 5 & 31 & 7 & Daniel-Rops & 14 & 6 & 1 \\
\hline Buck P. & 58 & 74 & 66 & Dante & 16 & 20 & 22 \\
\hline Bulgakov & 1 & 18 & 13 & Darwin & 6 & 6 & 7 \\
\hline Burnett $F$. & 9 & 8 & 9 & Daudet & 19 & 17 & 13 \\
\hline Burroughs E. & 8 & 28 & 19 & De Amicis & 7 & 7 & 15 \\
\hline Caesar & 6 & 8 & 7 & Defoe & 31 & 36 & 51 \\
\hline Caldwell E. & 23 & 17 & 8 & Deighton & - & 9 & 15 \\
\hline Caldwell T. & 9 & 11 & 29 & De La Roche & 15 & 16 & 12 \\
\hline Calvino & 6 & 8 & 14 & Delly & 18 & 3 & 7 \\
\hline Camus & 22 & 35 & 28 & Descartes & 8 & 10 & 11 \\
\hline Čapek & 15 & 15 & 14 & Dick Ph. & 1 & 5 & 17 \\
\hline Capote & 6 & 12 & 12 & Dickens Ch. & 58 & 61 & 67 \\
\hline Carnegie D. & 9 & 9 & 12 & Diderot & 8 & 10 & 10 \\
\hline Carr J. Dickson & 27 & 17 & 16 & /Walt Disney/ & 29 & 55 & 199 \\
\hline Carroll & 11 & 17 & 35 & Dostoevsky & 87 & 88 & 78 \\
\hline /Nick Carter/ & - & 31 & 41 & Doyle A. Conan & 32 & 33 & 50 \\
\hline Cartland B. & 3 & 20 & 116 & Dreiser & 17 & 12 & 9 \\
\hline
\end{tabular}




\begin{tabular}{|c|c|c|c|c|c|c|c|}
\hline Druon & 10 & 10 & 10 & Gogol & 37 & 37 & 32 \\
\hline Dürrenmatt & 11 & 13 & 7 & Goldoni & 9 & 7 & 6 \\
\hline Dumas (fils) & 6 & 7 & 7 & Golon A. & 9 & 22 & 22 \\
\hline Dumas (père) & 48 & 59 & 53 & Goncharov I.A. & 9 & 5 & 6 \\
\hline Du Maurier & 23 & 28 & 22 & Gordon R. & 11 & 10 & 9 \\
\hline Durant W. & 10 & 11 & 9 & Gor'kij & 84 & 75 & 67 \\
\hline Durrell G. & 4 & 10 & 15 & Goscinny & - & 15 & 80 \\
\hline Eden D. & 1 & 14 & 14 & Goudge E. & 8 & 10 & 9 \\
\hline Eliade & 4 & 6 & 13 & Graham B. & 5 & 10 & 8 \\
\hline Eliot T.S. & 8 & 9 & 6 & Graham W. & 5 & 7 & 8 \\
\hline Engels & 66 & 56 & 45 & Grass G. & 2 & 9 & 12 \\
\hline Erasmus & 6 & 12 & 8 & Graves R. & 6 & 6 & 13 \\
\hline Erenburg & 17 & 10 & 7 & Gray B. & 4 & 18 & 6 \\
\hline Esenin & 4 & 9 & 8 & Grée A. & - & 15 & 17 \\
\hline Euripides & 14 & 15 & 15 & Greene G. & 48 & 43 & 49 \\
\hline Evely L. & 3 & 16 & 4 & Grey Z. & 28 & 31 & 20 \\
\hline Eysenck & 3 & 7 & 13 & Grimm, brothers & 51 & 65 & 120 \\
\hline Fadeev & 10 & 7 & 7 & Gripe M. & 1 & 6 & 15 \\
\hline Farley & 8 & 8 & 6 & Grover M. & 10 & 47 & 44 \\
\hline Fast $\mathrm{H}$. & 15 & 15 & 18 & Guardini R. & 21 & 5 & 2 \\
\hline Faulkner & 25 & 28 & 18 & Guareschi & 8 & 14 & 11 \\
\hline Fedin K.A. & 10 & 4 & 5 & Guillot $R$. & 12 & 15 & 6 \\
\hline Feuchtwanger & 15 & 9 & 6 & Häring B. & 3 & 14 & 4 \\
\hline Fischer M.L. & 2 & 8 & 21 & Haggard, H.R. & 12 & 14 & 9 \\
\hline Fitzgerald F. & 7 & 11 & 15 & Hailey A. & 3 & 15 & 20 \\
\hline Flaubert & 22 & 26 & 26 & Halliday B. & 14 & 17 & 2 \\
\hline Fleming I. & 10 & 47 & 16 & Hammet D. & 5 & 10 & 13 \\
\hline Forester C.S. & 13 & 11 & 8 & Hamsun $\mathrm{K}$. & 18 & 13 & 14 \\
\hline Forsyth F. & & 7 & 25 & Han, Suyin & 7 & 11 & 6 \\
\hline France A. & 19 & 11 & 12 & Hardy $\mathrm{T}$. & 10 & 10 & 11 \\
\hline Frank A. & 9 & 5 & 7 & Hartog J. & 7 & 9 & 4 \\
\hline Freud & 15 & 32 & 35 & Hašek & 12 & 10 & 12 \\
\hline Frisch M. & 6 & 9 & 10 & Hassel S. & 4 & 12 & 17 \\
\hline Fromm & 8 & 23 & 36 & Hauff W. & 9 & 8 & 7 \\
\hline Gajdar & 23 & 15 & 18 & Hawthorne & 11 & 9 & 9 \\
\hline Galbraith & 5 & 13 & 15 & Hegel & 8 & 17 & 17 \\
\hline Gallico & 16 & 22 & 17 & Heidegger & 6 & 7 & 8 \\
\hline Galsworthy & 14 & 18 & 9 & Heine & 10 & 7 & 7 \\
\hline Gamzatov & 3 & 7 & 12 & Heinlein & 5 & 12 & 21 \\
\hline Gandhi M. & 14 & 11 & 6 & Hemingway & 49 & 65 & 62 \\
\hline Garaudy & 3 & 12 & 7 & Henry 0. & 8 & 8 & 6 \\
\hline García Lorca & 13 & 12 & 14 & Hergé & 6 & 16 & 30 \\
\hline García Márquez & $\overline{-1}$ & 7 & 29 & Hesse H. & 15 & 35 & 49 \\
\hline Gardner E.S. & 73 & 57 & 46 & Heyer G. & 7 & 20 & 33 \\
\hline Gary R. & 6 & 6 & 11 & Heyderdahl & 13 & 11 & 10 \\
\hline Gaskin C. & 5 & 11 & 15 & Higgins J. & & 3 & 28 \\
\hline al Ghazzali & 4 & 10 & 8 & Highsmith P. & 3 & 9 & 19 \\
\hline Gibran & 6 & 10 & 24 & Hikmet & 8 & 7 & 7 \\
\hline Gide & 19 & 22 & 11 & Hitchcock & 4 & 18 & 31 \\
\hline Goethe & 37 & 36 & 38 & Hodakov Ju.V. & 1 & 1 & 23 \\
\hline
\end{tabular}




\begin{tabular}{|c|c|c|c|c|c|c|c|}
\hline Hoffmann E.T.A. & 7 & 9 & 11 & Lang M. & 3 & 10 & 12 \\
\hline Holt V. & 5 & 20 & 37 & Lawrence D.H. & 17 & 19 & 24 \\
\hline Homer & 31 & 36 & 36 & Laxness & 14 & 8 & 7 \\
\hline Horatius & 8 & 7 & 6 & Leblanc M. & 14 & 16 & 9 \\
\hline Howard H. & 6 & 9 & 10 & Le Carré & 2 & 17 & 23 \\
\hline Hoxha E. & 2 & 6 & 25 & Lem $\mathbf{S}$. & 5 & 11 & 29 \\
\hline Hruščev & 116 & 2 & 1 & Lenin & 226 & 269 & 418 \\
\hline Hugo & 41 & 44 & 33 & Leonov L. & 8 & 9 & 4 \\
\hline Huxley A. & 18 & 19 & 24 & Lermontov & 15 & 10 & 10 \\
\hline Ibsen & 19 & 16 & 18 & Leskov & 10 & 9 & 6 \\
\hline Innes $\mathrm{H}$. & 15 & 12 & 16 & Lessing D. & 2 & 5 & 20 \\
\hline Ionesco & 6 & 11 & 7 & Lewis C.S. & 9 & 7 & 21 \\
\hline Irish W. & 8 & 8 & 7 & Lewis $\mathrm{S}$. & 14 & 8 & 3 \\
\hline James H. & 8 & 14 & 17 & Lindgren A. & 27 & 46 & 53 \\
\hline Janson, Hank & 6 & 31 & 16 & Lobsang Rampa & 3 & 9 & 25 \\
\hline Jansson T. & 4 & 12 & 14 & Lofting $\mathrm{H}$. & 6 & 9 & 7 \\
\hline Jaspers & 8 & 11 & 4 & London J. & 53 & 68 & 107 \\
\hline Joannes XXIII & 11 & 10 & 3 & Lorenz K. & 2 & 9 & 10 \\
\hline Joannes Paulus II & & & 52 & Lukacz G. & 5 & 12 & 12 \\
\hline Johns W.E. & 30 & 32 & 10 & Luther M. & 10 & 9 & 8 \\
\hline Jones J. & 6 & 7 & 7 & McBain E. & 17 & 27 & 34 \\
\hline Joyce & 6 & 12 & 15 & MacDonald J.D. & 6 & 17 & 9 \\
\hline Jung C.G. & 9 & 14 & 17 & MacDonald J.R. & 7 & 13 & 18 \\
\hline Kästner E. & 19 & 18 & 12 & MacDonnell J.E. & 4 & 13 & 3 \\
\hline Kafka & 13 & 25 & 29 & Machiavelli & 8 & 8 & 11 \\
\hline Kalidasa & 14 & 9 & 8 & MacInnes H. & 3 & 11 & 7 \\
\hline Kane H. & 8 & 9 & 3 & MacLean A. & 18 & 59 & 76 \\
\hline Kant I. & 9 & 16 & 13 & Mailer N. & 4 & 15 & 11 \\
\hline Kardelj & 5 & 2 & 12 & Majakovskij & 21 & 23 & 18 \\
\hline Kataev & 14 & 13 & 12 & Makarenko & 17 & 10 & 14 \\
\hline Kawabata & 2 & 13 & 7 & Makaryčev & & & 40 \\
\hline Kazantakes & 12 & 15 & 13 & Mallorqui J. & 18 & 3 & - \\
\hline Keene D. & 11 & 7 & 2 & Malot H. & 10 & 10 & 8 \\
\hline Kent L. & 13 & 29 & 25 & Malraux & 7 & 10 & 10 \\
\hline Kierkegaard & 18 & 13 & 12 & Mann T. & 27 & 28 & 28 \\
\hline Kipling & 28 & 28 & 31 & Mao, Tse-tung & 16 & 27 & 31 \\
\hline Kirst H.H. & 15 & 23 & 17 & Marcuse & 1 & 16 & 9 \\
\hline Kishon & 2 & 10 & 20 & Marryat F. & 9 & 7 & 7 \\
\hline Koestler & 8 & 10 & 9 & Maršak S.Ja. & 17 & 11 & 16 \\
\hline Kolmogorvo & 1 & 1 & 48 & Marsh N. & 8 & 12 & 10 \\
\hline Konsalik & 6 & 21 & 56 & Marx K. & 73 & 112 & 157 \\
\hline Krishnamurti J. & 6 & 9 & 18 & Masterson L. & & 9 & 34 \\
\hline Krupskaja & 14 & 12 & 7 & Mather A. & & - & 29 \\
\hline Kuprin & 10 & 7 & 12 & Maugham & 48 & 37 & 21 \\
\hline La Fontaine & 8 & 9 & 22 & Maupassant & 46 & 41 & 29 \\
\hline Lafuente E. & 8 & 25 & 7 & Mauriac F. & 24 & 14 & 6 \\
\hline Lagerkvist $P$. & 8 & 8 & 3 & Maurois & 29 & 24 & 14 \\
\hline Lagerlöf S. & 21 & 13 & 17 & May K. & 26 & 51 & 25 \\
\hline L'Amour & 7 & 20 & 21 & Melville $\mathrm{H}$. & 17 & 22 & 26 \\
\hline Landau L.D. & 6 & 14 & 16 & Mérimée & 13 & 8 & \\
\hline
\end{tabular}




\begin{tabular}{|c|c|c|c|c|c|c|c|}
\hline Merton T. & 10 & 7 & 4 & Puzo M. & & 9 & 12 \\
\hline Michener & 9 & 8 & 15 & al Qoran & 8 & 8 & 11 \\
\hline Mihalkov & 14 & 6 & 10 & Queen E. & 32 & 42 & 32 \\
\hline Miller A. & 9 & 10 & 6 & Quentin P. & 15 & 14 & 7 \\
\hline Miller $\mathrm{H}$. & 13 & 25 & 28 & Quoist M. & 8 & 14 & 8 \\
\hline Milne & 7 & 12 & 16 & Rahner K. & 9 & 24 & 12 \\
\hline Molière & 21 & 27 & 25 & Raspe & 8 & 6 & 7 \\
\hline Monsarrat N. & 11 & 7 & 5 & Reich W. & 4 & 9 & 12 \\
\hline Montgomery L.M. & 8 & 10 & 7 & Reid T.M. & 11 & 8 & 10 \\
\hline Moravia & 25 & 40 & 26 & Remarque & 24 & 28 & 20 \\
\hline Moro M.I. & & 3 & 33 & Rilke & 14 & 10 & 14 \\
\hline Morris D. & - & 11 & 11 & Robbins $\mathrm{H}$. & 4 & 22 & 48 \\
\hline Murdoch I. & 4 & 14 & 11 & Robeson $\mathrm{K}$. & & 10 & 10 \\
\hline Muskett N. & 6 & 4 & 4 & Rodari G. & 9 & 10 & 14 \\
\hline Nabokov & 10 & 16 & 16 & Rolland R. & 26 & 18 & 12 \\
\hline Neruda & 4 & 15 & 25 & Rousseau & 15 & 16 & 15 \\
\hline Nietzsche & 10 & 18 & 28 & Russell B. & 25 & 33 & 21 \\
\hline Nin A. & 1 & 3 & 21 & Sade & 3 & 13 & 10 \\
\hline Nosov N.N. & 23 & 8 & 11 & Sadoveanu & 12 & 6 & 6 \\
\hline 'Omar Khayyam & 10 & 9 & 8 & Sagan F. & 20 & 23 & 28 \\
\hline Orwell & 6 & 12 & 15 & Saint-Exupéry & 16 & 22 & 25 \\
\hline Ostrovskij N. & 11 & 9 & 12 & Salgari & 19 & 10 & 41 \\
\hline Overholser & 7 & 13 & 3 & Salinger & 5 & 11 & 10 \\
\hline Ovid & 9 & 15 & 10 & Sand $\mathrm{G}$. & 7 & 9 & 10 \\
\hline Parker B. & 20 & 11 & 5 & Saroyan & 12 & 8 & 8 \\
\hline Parkinson C. & 5 & 10 & 8 & Sartre & 28 & 43 & 39 \\
\hline Pascal & 7 & 7 & 6 & Sayers D. & 12 & 15 & 14 \\
\hline Pasternak & 14 & 12 & 6 & Scarry $R$. & 1 & 14 & 40 \\
\hline Patten L. & 5 & 12 & 13 & Schiller F. & 16 & 10 & 9 \\
\hline Paul VI & 2 & 33 & 14 & Schlink M.B. & 2 & 12 & 12 \\
\hline Paustovskij & 14 & 16 & 11 & Schulz Ch. M. & 1 & 20 & 35 \\
\hline Pavese & 5 & 10 & 10 & Schweitzer A. & 11 & 6 & 3 \\
\hline Peale N. & 5 & 4 & 14 & Scott W. & 28 & 26 & 29 \\
\hline Perel'man Ja.I. & 8 & 6 & 10 & Seneca & 7 & 10 & 9 \\
\hline Perrault & 20 & 20 & 79 & Shakespeare & 120 & 103 & 99 \\
\hline Peryškin A.V. & 1 & 2 & 18 & Shalom Aleichem & 9 & 8 & 4 \\
\hline Peterson $\mathrm{H}$. & 6 & 11 & 13 & Shaw G.B. & 19 & 13 & 10 \\
\hline Piaget & 4 & 25 & 28 & Shaw I. & 10 & 7 & 28 \\
\hline Pirandello & 13 & 11 & 8 & Sheen F. & 17 & 2 & - \\
\hline Plato & 37 & 42 & 36 & Shirreffs & 4 & 10 & 6 \\
\hline Plautus & 7 & 9 & 5 & Shute N. & 19 & 12 & 6 \\
\hline Plehanov & 10 & 5 & 10 & Sienkiewicz & 17 & 19 & 12 \\
\hline Plutarchus & 10 & 9 & 8 & Silverberg & - & 7 & 17 \\
\hline Poe & 24 & 31 & 40 & Simak C.D. & 2 & 8 & 12 \\
\hline Polevoj & 11 & 8 & 9 & Simenon & 72 & 120 & 91 \\
\hline Prather R. & 12 & 13 & 5 & Simonov & 8 & 14 & 14 \\
\hline Priestley J.B. & 8 & 8 & 4 & Singer I.B. & 1 & 9 & 32 \\
\hline Proust & 9 & 13 & 17 & Slaughter F. & 22 & 41 & 33 \\
\hline (Puranas) & 4 & 7 & 13 & Šolohov & 36 & 28 & 25 \\
\hline Pushkin & 46 & 42 & 42 & Sol ženicyn & 4 & 36 & 29 \\
\hline
\end{tabular}




\begin{tabular}{|c|c|c|c|c|c|c|c|}
\hline Sophocles & 20 & 22 & 18 & Updike & 1 & 11 & 12 \\
\hline Spillane M. & 27 & 26 & 14 & Uris L. & 9 & 18 & 18 \\
\hline Spock B. & 8 & 11 & 9 & Van Vogt A. & 2 & 10 & 13 \\
\hline Spyri J. & 20 & 17 & 42 & Vergilius & 14 & 15 & 17 \\
\hline Stalin & 20 & 8 & 14 & Verne J. & 113 & 124 & 176 \\
\hline Steinbeck & 51 & 50 & 34 & Vernes $\mathrm{H}$. & 12 & 11 & - \\
\hline Steiner R. & 10 & 16 & 34 & Vilenkin N. Ja & & 4 & 24 \\
\hline Stendhal & 32 & 32 & 32 & de Villiers G. & & 6 & 26 \\
\hline Stevenson R.L. & 40 & 50 & 68 & Vivekananda & 9 & 17 & 11 \\
\hline Stewart M. & 6 & 15 & 15 & Voltaire & 17 & 14 & 15 \\
\hline Stone I. & 8 & 12 & 11 & Vonnegut $\mathrm{K}$. & - & 6 & 15 \\
\hline Stout R. & 16 & 22 & 23 & de Vries A. & 8 & 7 & 5 \\
\hline Stowe H.B. & 16 & 19 & 19 & Wahlöö and $\mathrm{Sj}$ & 1118 & 34 & \\
\hline /Stratemeyer/ & 38 & 80 & 71 & Wallace E. & 28 & 41 & 54 \\
\hline Strindberg & 11 & 19 & 18 & Wallace I. & 2 & 10 & 22 \\
\hline Susann J. & & 6 & 16 & Wallace L. & 13 & 6 & \\
\hline Suteev V.G. & 11 & 7 & 5 & Waltari M. & 11 & 8 & \\
\hline Swift J. & 20 & 22 & 30 & Wells H. & 12 & 3 & 5 \\
\hline Tacitus & 6 & 8 & 8 & Wells H.G. & 18 & 16 & 22 \\
\hline Tagore R. & 52 & 32 & 22 & Werner L. & 6 & 7 & 25 \\
\hline Teilhard de Chardin & n 8 & 22 & 7 & West M.L. & 8 & 25 & 36 \\
\hline Tellado C. & 16 & 18 & 3 & Westlake D. & 1 & 18 & 13 \\
\hline Thackeray & 12 & 7 & 8 & White E.G. & 8 & 11 & 15 \\
\hline Thomas à Kempis & 9 & 5 & 7 & Wilde O. & 23 & 27 & 35 \\
\hline Thomas Aquinas & 11 & 9 & 7 & Wilder L. & 9 & 7 & 15 \\
\hline Tito & 6 & 7 & & Wilder $\mathbf{T}$. & 8 & 8 & 11 \\
\hline Tolkien & 2 & 10 & 25 & Williams $\mathrm{T}$. & 8 & 7 & 10 \\
\hline Tolstoy A.N. & 28 & 16 & 20 & Winspear V. & - & 3 & 20 \\
\hline Tolstoy L.N. & 117 & 95 & 100 & Wodehouse & 21 & 14 & 19 \\
\hline Toynbee & 10 & 10 & 7 & Wolde G. & & 5 & 21 \\
\hline Traven B. & 8 & 8 & 11 & Woolf V. & 5 & 5 & 21 \\
\hline Trevor & 4 & 10 & 7 & Wouk & 7 & 7 & 1 \\
\hline Trockij & 6 & 23 & 22 & Yerby & 8 & 12 & 18 \\
\hline Troyat & 10 & 13 & 12 & Zilahy L. & 7 & 9 & \\
\hline Turgenev & 46 & 37 & 29 & Živkov & 5 & 10 & 1 \\
\hline Twain & 59 & 67 & 80 & Zola & 49 & 43 & 33 \\
\hline Undset $\mathrm{S}$. & 14 & 9 & 6 & Zweig S. & 35 & 26 & 20 \\
\hline \multicolumn{7}{|c|}{$\begin{array}{l}\text { TABLE } 9 \\
\text { SPECTRA (1975-1979) } \\
\text { translated books) }\end{array}$} & \\
\hline
\end{tabular}

E - United Kingdom, United States; EE - GDR, Poland, Czechoslovakia, Hungary, Romania, Bulgaria; Fr - France; G - FRG, Austria, Switzerland; It - Italy; J - Japan; LA - Latin America; NB — Netherlands, Belgium; Sc — Norway, Denmark, Sweden, Finland; Sp — Spain; $\mathrm{T}$ - Turkey; $\mathrm{Y}$ - Yugoslavia.

\begin{tabular}{lccccccccccccc} 
& E & Sc & NB & Fr & Sp & It & G & EE & Y & USSR $^{1}$ & T & J & LA \\
\hline Alcott & 1 & 1 & 2 & 49 & 18 & $\ldots$ & & & & 8 & 6 & 17
\end{tabular}




\begin{tabular}{|c|c|c|c|c|c|c|c|c|c|c|c|c|c|}
\hline $\begin{array}{l}\text { Andersen } \\
\text { (Arabian }\end{array}$ & 22 & 11 & 20 & 28 & 69 & 11 & 7 & 16 & 34 & 20 & 27 & 16 & \\
\hline Nights) & 5 & 8 & 9 & 4 & 42 & 15 & 6 & 6 & 6 & 7 & 27 & 2 & \\
\hline Asimov & & 9 & 16 & 13 & 27 & 19 & 9 & 1 & 13 & 1 & & 22 & \\
\hline Balzac & 10 & 2 & 2 & & 12 & 6 & 10 & 19 & 51 & 7 & 20 & 11 & \\
\hline oir & 3 & 2 & 11 & & & 7 & 15 & 2 & & & 1 & 1 & \\
\hline (Bible, N.T.) & 65 & 8 & 44 & 57 & 82 & 43 & 49 & 29 & 6 & & 9 & 14 & 48 \\
\hline Bible, O.T.) & 50 & 4 & 38 & 62 & 52 & 42 & 46 & 15 & 3 & & & 2 & \\
\hline Blyton & & 75 & 48 & 38 & 43 & 3 & 52 & & & & 57 & 4 & \\
\hline öll & 11 & 9 & 23 & 5 & 4 & 11 & 1 & 3 & 5 & & & 2 & \\
\hline recht & 11 & 5 & 5 & 4 & 5 & 10 & & 9 & 6 & 2 & 29 & 4 & \\
\hline Brežı & 2 & 3 & & 3 & 1 & 3 & 1 & 21 & 3 & 216 & 14 & 2 & \\
\hline Brown C & & 30 & 1 & 37 & & & 14 & & & & 9 & & \\
\hline Buck & & 7 & 10 & 20 & 22 & 15 & 39 & & 34 & & 9 & 7 & \\
\hline Carrol & 2 & 2 & 8 & 12 & 21 & 8 & 3 & 3 & 22 & 3 & 16 & 10 & \\
\hline Nick Carter/ & & 47 & 24 & & & & 7 & & & & & 1 & \\
\hline Cartla & & 57 & 22 & 20 & & & 17 & & & & 236 & & 94 \\
\hline Ceauçescu & & & & & & 1 & & 73 & & & & & \\
\hline Chehov & 12 & 4 & 7 & & 4 & 11 & 11 & 20 & 22 & 12 & 7 & 16 & \\
\hline Chase & & 8 & 2 & 10 & 4 & & 8 & 2 & 2 & & 7 & 2 & \\
\hline Chri & 1 & 50 & 39 & 37 & 26 & 9 & 72 & 11 & 83 & 1 & 93 & 54 & 14 \\
\hline Cook & & 11 & 29 & 2 & 2 & & 11 & & & & 2 & & \\
\hline Coope & & 5 & 5 & 11 & 11 & 11 & 9 & 10 & 2 & 5 & 9 & 1 & \\
\hline Cronin & & 3 & 5 & 13 & 2 & 28 & 19 & 3 & 24 & 1 & 24 & 11 & \\
\hline lefoe & & 5 & 9 & 11 & 26 & 12 & 9 & 10 & 29 & 4 & 29 & 7 & \\
\hline & 1 & 8 & 11 & 1 & 3 & 13 & 17 & 10 & 21 & 4 & 18 & 7 & \\
\hline$/ \mathrm{Wa}$ & $/ 1$ & 114 & 9 & 76 & 35 & 14 & 25 & & 24 & 2 & 7 & 5 & \\
\hline Dost & 8 & 7 & 12 & 6 & 22 & 13 & 18 & 20 & 50 & 10 & 23 & 28 & \\
\hline Doy & & 6 & 4 & 10 & 2 & 3 & 10 & 5 & 3 & 4 & 7 & 27 & \\
\hline Dumas (père) & 9 & 8 & 3 & & 21 & 23 & 12 & 14 & 6 & 17 & 20 & 11 & \\
\hline Engels & 1 & 3 & & 2 & 8 & 7 & & 8 & 27 & 36 & 45 & 7 & \\
\hline reu & 9 & 2 & 5 & 9 & 20 & 37 & 1 & 1 & 16 & & 16 & 3 & 19 \\
\hline Fromm & & 5 & 3 & 5 & 7 & 8 & 7 & 1 & 13 & & 14 & 3 & 33 \\
\hline & & 4 & 11 & 3 & 1 & 5 & 25 & 5 & & & 25 & 24 & \\
\hline & 12 & 4 & 5 & & 7 & 9 & 1 & & 13 & 9 & & 11 & \\
\hline & 4 & 4 & 5 & 3 & 2 & 4 & 7 & 10 & 29 & 5 & 9 & 5 & \\
\hline & 5 & 9 & 2 & 4 & 16 & 6 & 7 & 27 & 38 & 33 & 98 & 5 & \\
\hline & 35 & 50 & & 1 & 40 & 1 & 13 & 一 & & - & 14 & 1 & \\
\hline & & 15 & 8 & 18 & 4 & 28 & 21 & 8 & 5 & 1 & 2 & 9 & \\
\hline Grim & 39 & 29 & 20 & 36 & 139 & 55 & 1 & 4 & 42 & 8 & 41 & 3 & 17 \\
\hline Grover & & 83 & 2 & & & & 1 & & & & & & \\
\hline & & 5 & 8 & 10 & 1 & 12 & 22 & 11 & 40 & & 20 & 7 & \\
\hline & 13 & 10 & 16 & 8 & 33 & 6 & - & 2 & 19 & 1 & & 8 & \\
\hline Hever & & 1 & 5 & 1 & 2 & 7 & & - & & & 5 & & \\
\hline itche & & 16 & 1 & 5 & & 13 & 8 & & & & 2 & 3 & \\
\hline
\end{tabular}




\begin{tabular}{|c|c|c|c|c|c|c|c|c|c|c|c|c|c|}
\hline Holt & & 14 & 8 & 5 & 6 & & 16 & - & 14 & & 14 & 1 & 7 \\
\hline Homer & 6 & 5 & 8 & 7 & 24 & 8 & 6 & 3 & 14 & 3 & 9 & 1 & 7 \\
\hline Hoxha & 1 & 3 & 1 & 3 & & 1 & 2 & & & & 41 & & \\
\hline Hugo & 3 & 3 & 3 & & 8 & 4 & 2 & 10 & 9 & 10 & 38 & 6 & \\
\hline Kipling & & 3 & 2 & 10 & 9 & 10 & 5 & 8 & 9 & 8 & 25 & 2 & \\
\hline Kolmogorov & 1 & & & 1 & - & & & 1 & & 83 & & & \\
\hline Konsalik & 15 & 3 & 70 & 35 & 1 & 1 & 6 & & 14 & & 5 & & 10 \\
\hline Lem & 10 & 3 & 2 & 5 & 5 & 2 & 10 & 8 & 10 & 2 & & 5 & 1 \\
\hline Lenin & 4 & 6 & 1 & 19 & 21 & 5 & 3 & 93 & 55 & 456 & 316 & & \\
\hline Lindgren & 20 & 36 & 15 & 1 & 7 & 8 & 20 & 4 & 16 & 5 & 7 & 6 & \\
\hline Lobsang & & & & & & & & & & & & & \\
\hline Rampa & & & 1 & 6 & 16 & & & & & & 2 & 1 & 96 \\
\hline London & & 22 & 5 & 42 & 12 & 35 & 47 & 34 & 45 & 19 & 117 & 4 & \\
\hline McBain & & 23 & 10 & 9 & 8 & 4 & 7 & 3 & & 5 & 22 & 1 & \\
\hline Maclean & & 49 & 76 & 5 & 6 & 19 & 14 & 3 & 10 & - & 14 & 14 & \\
\hline Mann T. & 10 & 4 & 5 & 7 & 9 & 8 & 1 & 12 & 6 & 4 & 2 & 3 & \\
\hline Mao & 9 & 6 & 5 & 86 & 10 & 11 & 4 & & 5 & & 61 & 2 & \\
\hline Marx & 20 & 10 & 7 & 27 & 31 & 37 & 1 & 39 & 136 & 106 & 110 & 16 & 18 \\
\hline Masterson & 9 & 49 & & & 2 & & 1 & & & & & & \\
\hline Maupassant & 7 & 2 & 10 & & 2 & 8 & 9 & 8 & 5 & 5 & 7 & 5 & \\
\hline May & 3 & - & 36 & & 15 & 11 & & 6 & 11 & & & 3 & \\
\hline Miller $\mathbf{H}$. & & 3 & 1 & 12 & 9 & 6 & 14 & 1 & 10 & & & 4 & \\
\hline Neruda & 9 & 7 & 2 & 8 & & 4 & 5 & 12 & 22 & 6 & 7 & 2 & \\
\hline Perrault & 11 & - & 13 & 3 & 122 & 6 & 2 & 4 & 10 & 2 & 41 & 2 & \\
\hline Piage & 15 & 2 & 1 & 1 & 13 & 9 & 9 & 1 & 3 & & & 9 & 44 \\
\hline Plato & 13 & 3 & 6 & 5 & 10 & 4 & 12 & 3 & 9 & - & 5 & 13 & 10 \\
\hline & 1 & 3 & 7 & 14 & 15 & 7 & 12 & 3 & 9 & 2 & 7 & 4 & 8 \\
\hline Pushkin & 12 & 1 & 2 & 2 & - & 5 & 5 & 15 & 24 & 23 & 7 & 3 & \\
\hline Queen & & 5 & 34 & 3 & 9 & 5 & 12 & 2 & & & 2 & 32 & \\
\hline Robbins H. & & 11 & 12 & 5 & 24 & 10 & 12 & & 6 & & 41 & 4 & 30 \\
\hline Sagan F. & 8 & 3 & 20 & & 6 & 10 & 5 & - & 53 & 1 & 2 & 8 & \\
\hline Salg & & & 2 & 1 & 78 & & 2 & - & 6 & 1 & & & \\
\hline Sartre & 9 & 5 & 11 & 1 & 2 & 9 & 22 & 1 & 6 & & 5 & 4 & 25 \\
\hline Scarry & 1 & 36 & 22 & 8 & 14 & 2 & 7 & & & & & 5 & \\
\hline Scott W. & & 2 & 4 & 8 & 18 & 5 & 5 & 8 & 3 & 3 & 5 & 2 & 5 \\
\hline Shakespeare & 3 & 9 & 3 & 14 & 24 & 25 & 22 & 32 & 37 & 6 & 2 & 15 & 18 \\
\hline Shaw & & 7 & 10 & 8 & 7 & 8 & 6 & 3 & 10 & & 7 & 2 & 12 \\
\hline Sime & 56 & 20 & 67 & & 22 & 27 & 29 & 6 & 3 & 3 & & 45 & 9 \\
\hline Sjöwa & 9 & 20 & 11 & & & & 11 & 3 & 2 & - & 14 & 14 & 1 \\
\hline & & 7 & 7 & 21 & 25 & 8 & 14 & & & & 2 & & 14 \\
\hline Solohe & 2 & 2 & & & & & 2 & 15 & 10 & 22 & 14 & 2 & \\
\hline Solženicyn & 21 & 8 & 9 & 10 & 6 & 14 & 14 & & & & 16 & 6 & \\
\hline Spy & 1 & 3 & 16 & 2 & 75 & 4 & & - & 18 & - & 41 & 3 & \\
\hline Stei & & 17 & 7 & 6 & 5 & 9 & 5 & 3 & 6 & 1 & 50 & 4 & \\
\hline Steiner & 10 & 11 & 10 & 14 & - & 12 & 4 & & & & & 4 & \\
\hline
\end{tabular}




\begin{tabular}{|c|c|c|c|c|c|c|c|c|c|c|c|c|c|}
\hline \multirow{3}{*}{\multicolumn{2}{|c|}{$\begin{array}{l}\text { Stendahl } 5 \\
\text { / Stratemeyer/ } \\
\text { Swift }\end{array}$}} & - & \multicolumn{2}{|l|}{1} & \multirow{2}{*}{$\begin{array}{r}8 \\
91\end{array}$} & \multirow{2}{*}{$\begin{array}{l}21 \\
11\end{array}$} & \multirow{2}{*}{$\begin{array}{r}5 \\
21\end{array}$} & \multirow{3}{*}{$\begin{array}{r}10 \\
1 \\
3\end{array}$} & \multirow{3}{*}{$\begin{array}{r}13 \\
6 \\
19\end{array}$} & \multirow[t]{2}{*}{10} & \multirow{2}{*}{$\begin{array}{r}5 \\
14\end{array}$} & \multirow{3}{*}{$\begin{array}{l}4 \\
1 \\
3\end{array}$} & \multirow{2}{*}{$\begin{array}{r}5 \\
41\end{array}$} \\
\hline & & 89 & 25 & 16 & & & & & & & & & \\
\hline & & 1 & 4 & 9 & 22 & 6 & 4 & & & 3 & 14 & & \\
\hline Tolstoy L. & 13 & 6 & 9 & 11 & 17 & 23 & 16 & 24 & 103 & 45 & 32 & 18 & 3 \\
\hline Trockij & 25 & 1 & 1 & 12 & 12 & 7 & 7 & & & & 18 & 8 & 15 \\
\hline Turgenev & 13 & 2 & 6 & 3 & 1 & 5 & 4 & 13 & 14 & 10 & & 2 & 2 \\
\hline Twain & & 12 & 6 & 9 & 32 & 11 & 25 & 14 & 34 & 8 & 23 & 20 & 13 \\
\hline Verne & 12 & 32 & 29 & 182 & 38 & 48 & 34 & 56 & 12 & 81 & 15 & 14 & \\
\hline Vilenkin & & & & 1 & & & & 1 & & 39 & & & \\
\hline Wallace E. & & 3 & 33 & 3 & - & 6 & 40 & & & & & 1 & 9 \\
\hline West M. & & 5 & 8 & 10 & 20 & 8 & 15 & 1 & 6 & & 11 & 1 & 46 \\
\hline Wilde & & 2 & 2 & 8 & 17 & 10 & 13 & 5 & 5 & 2 & 2 & 9 & 7 \\
\hline Wolde & 12 & 23 & 8 & 8 & & 3 & 5 & & & & & 8 & \\
\hline Zola & 2 & - & 2 & & 10 & 6 & 15 & 17 & 24 & 2 & 9 & 2 & 2 \\
\hline
\end{tabular}

Fig. 1 : PROPORTION OF TRANSLATED BOOKS AND THE SIZE OF THE COUNTRY

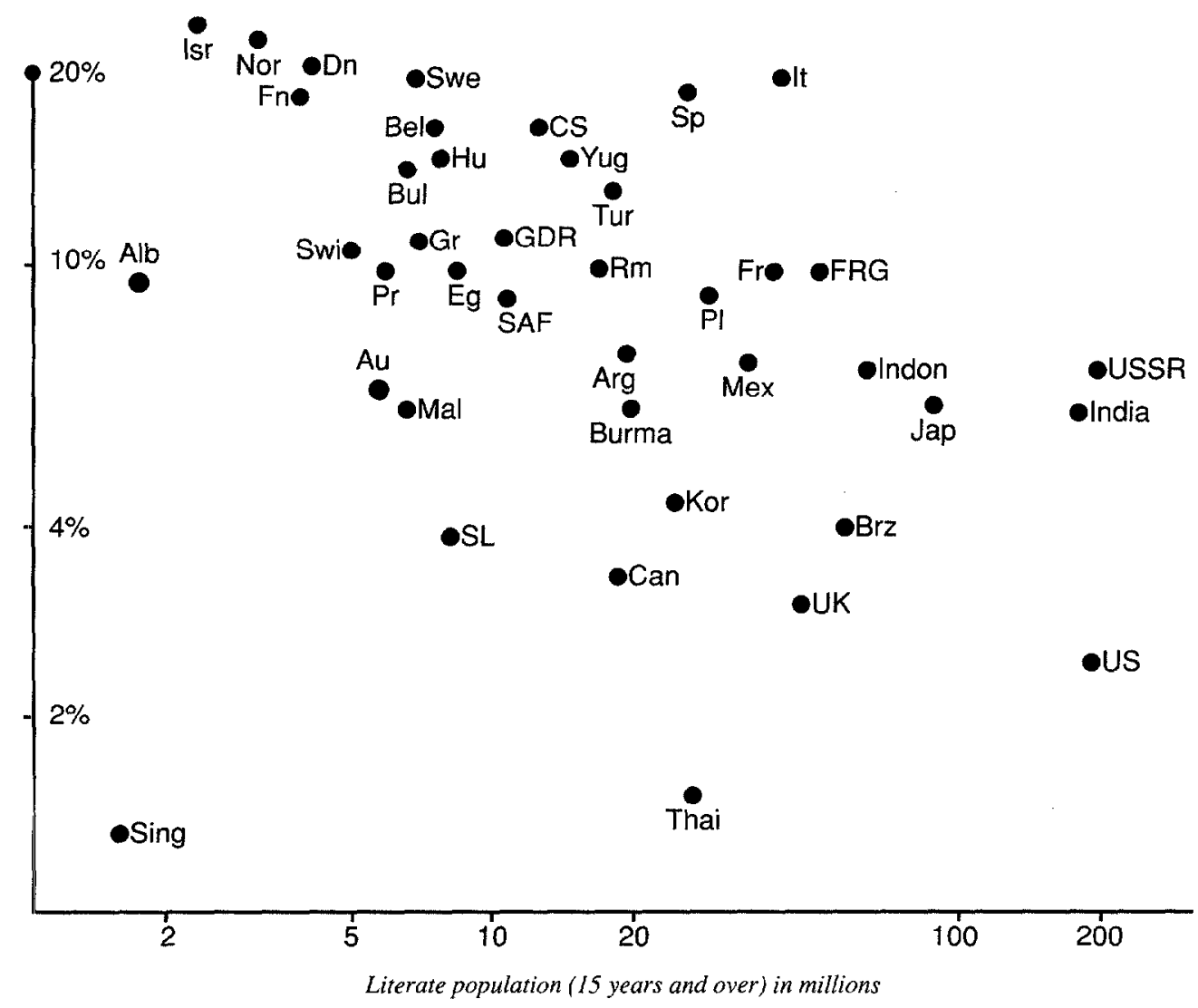


Fig. 2 : LINGUISTIC CLUSTERS OF COUNTRIES, 1960-1983

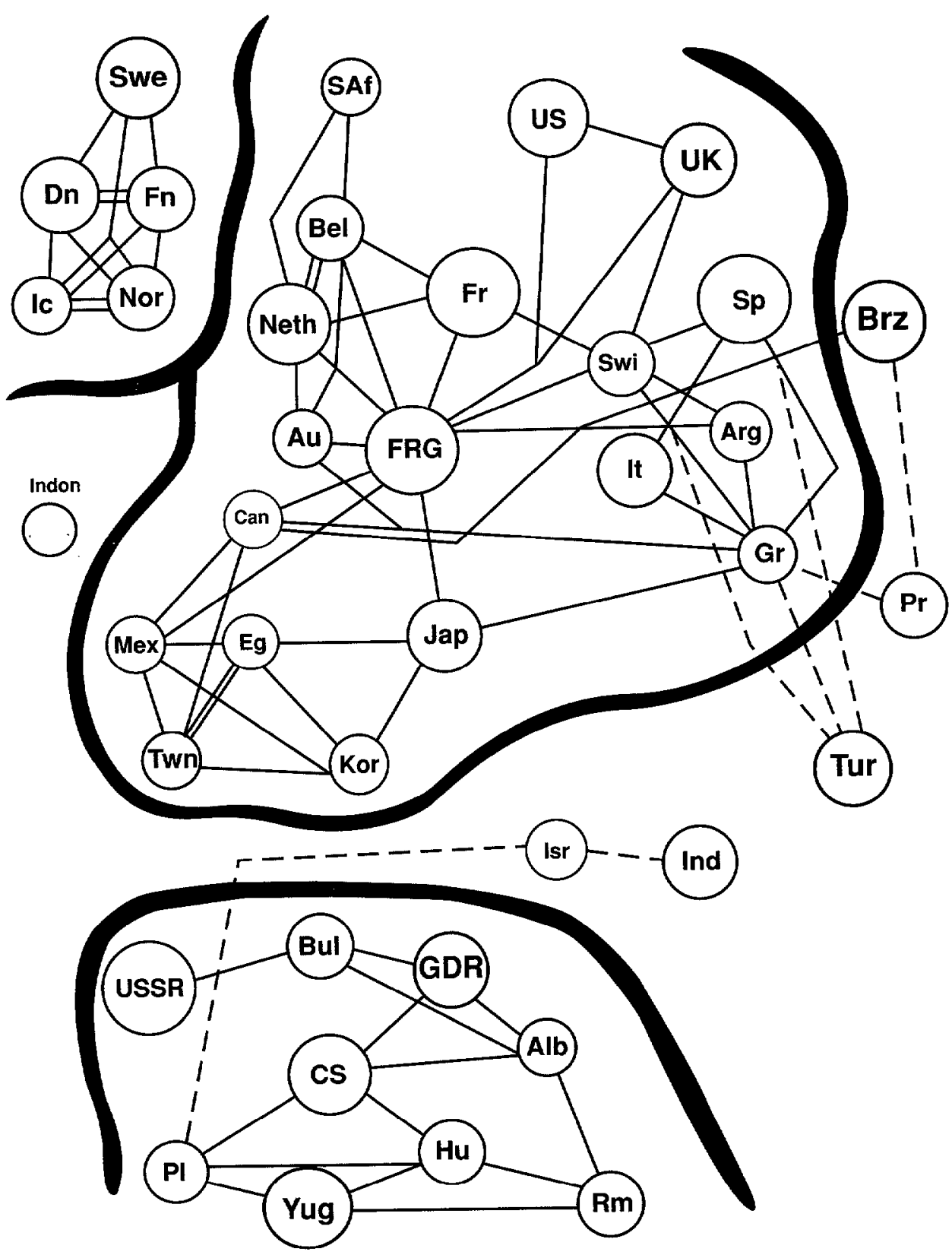


Fig. 3 : THEMATIC CLUSTERS OF COUNTRIES, 1960-1964

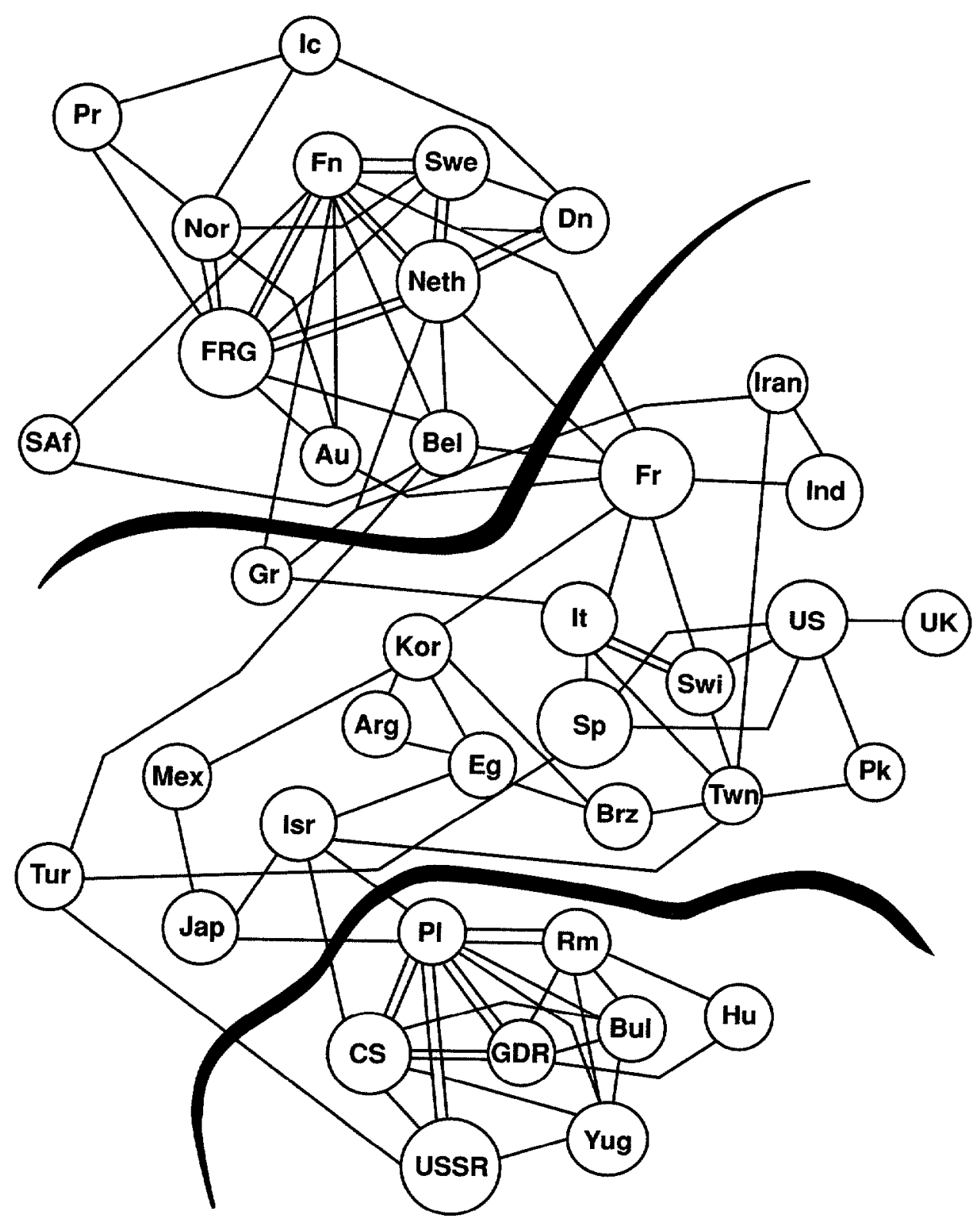


Fig. 4 : THEMATIC CLUSTERS OF COUNTRIES, 1975-1979

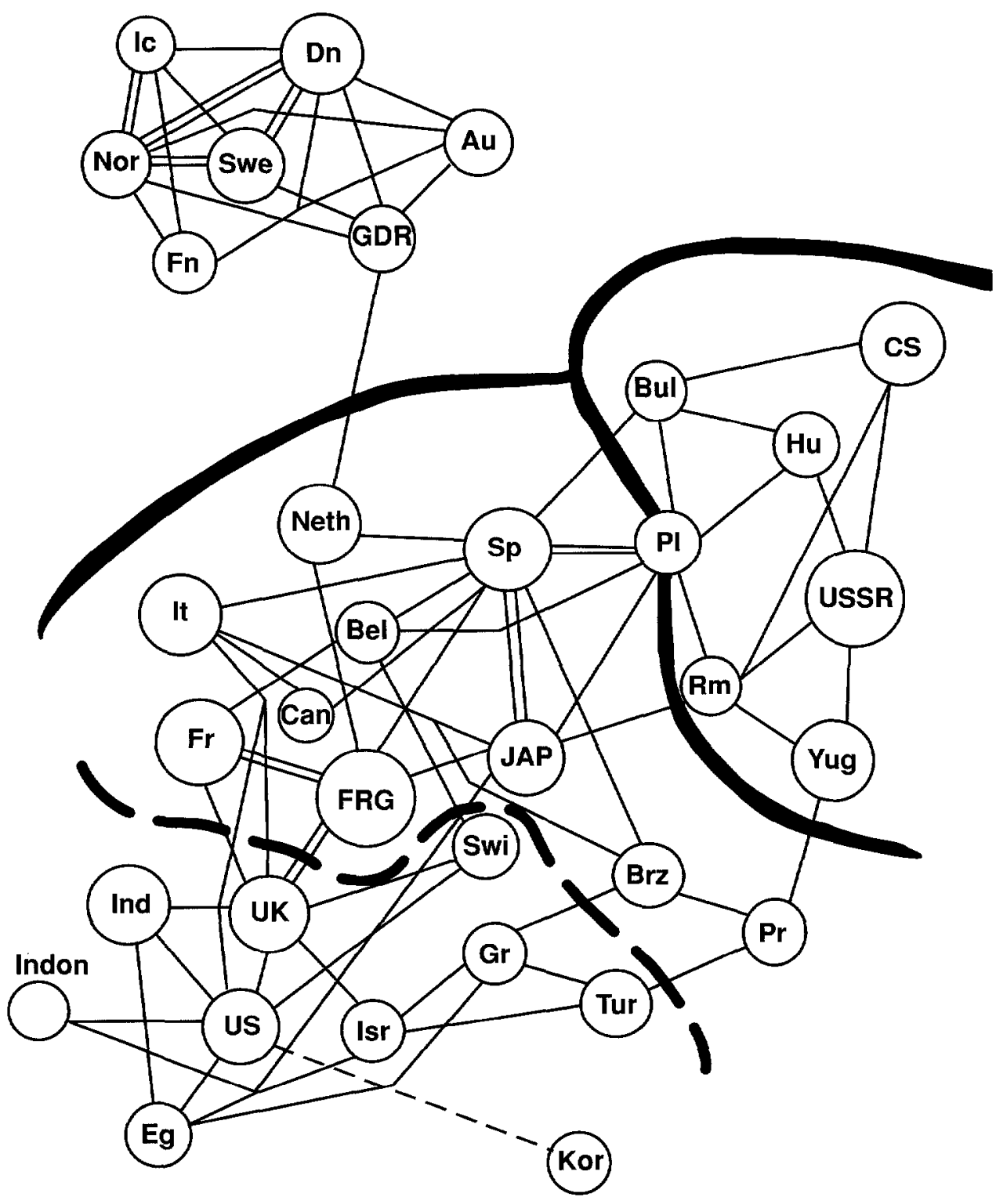


Fig. 5 : THEMATIC CLUSTERS OF COUNTRIES, 1980-1983

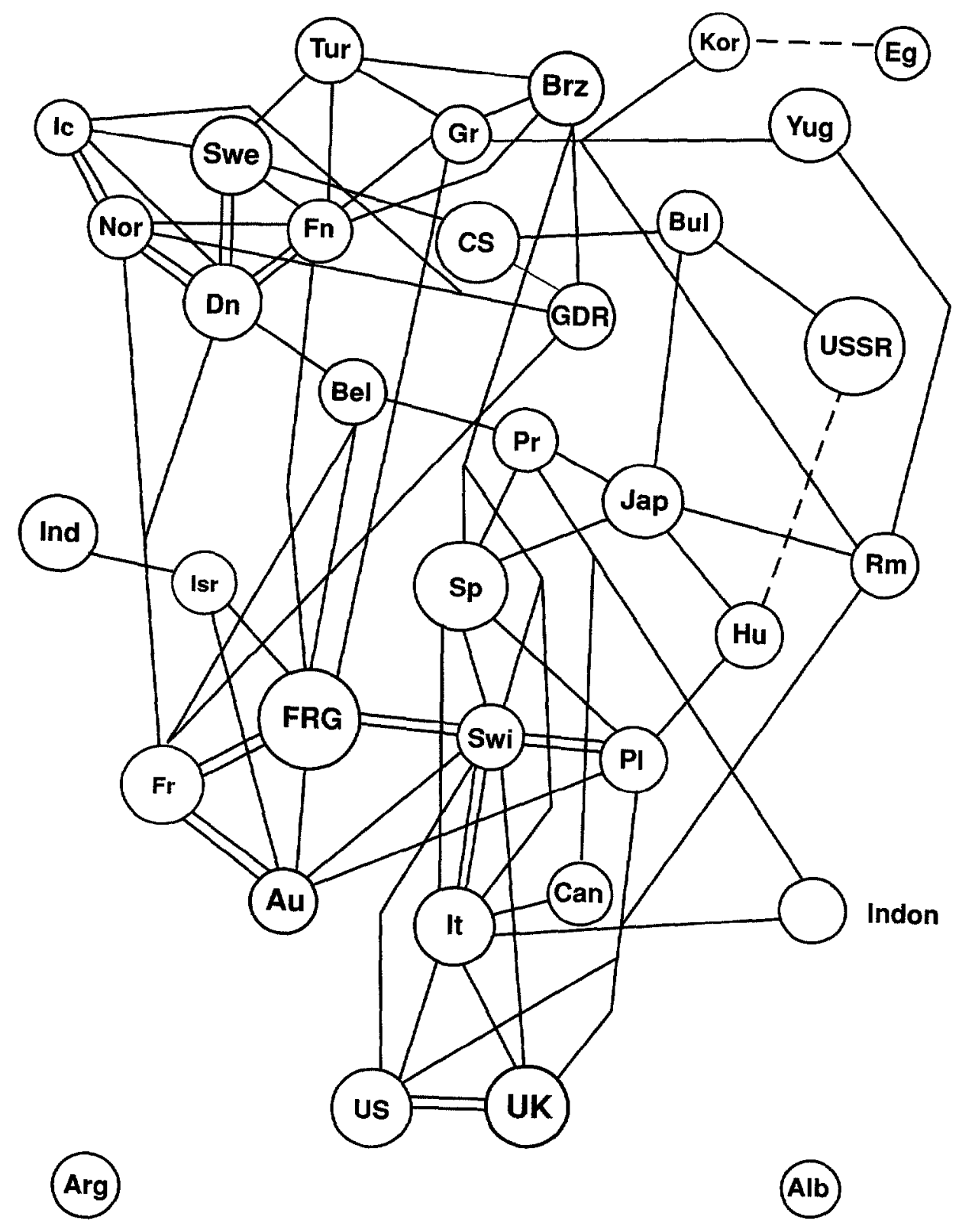


Fig. 6 : AUTHORS' CLUSTERS OF COUNTRIES, 1975-1979

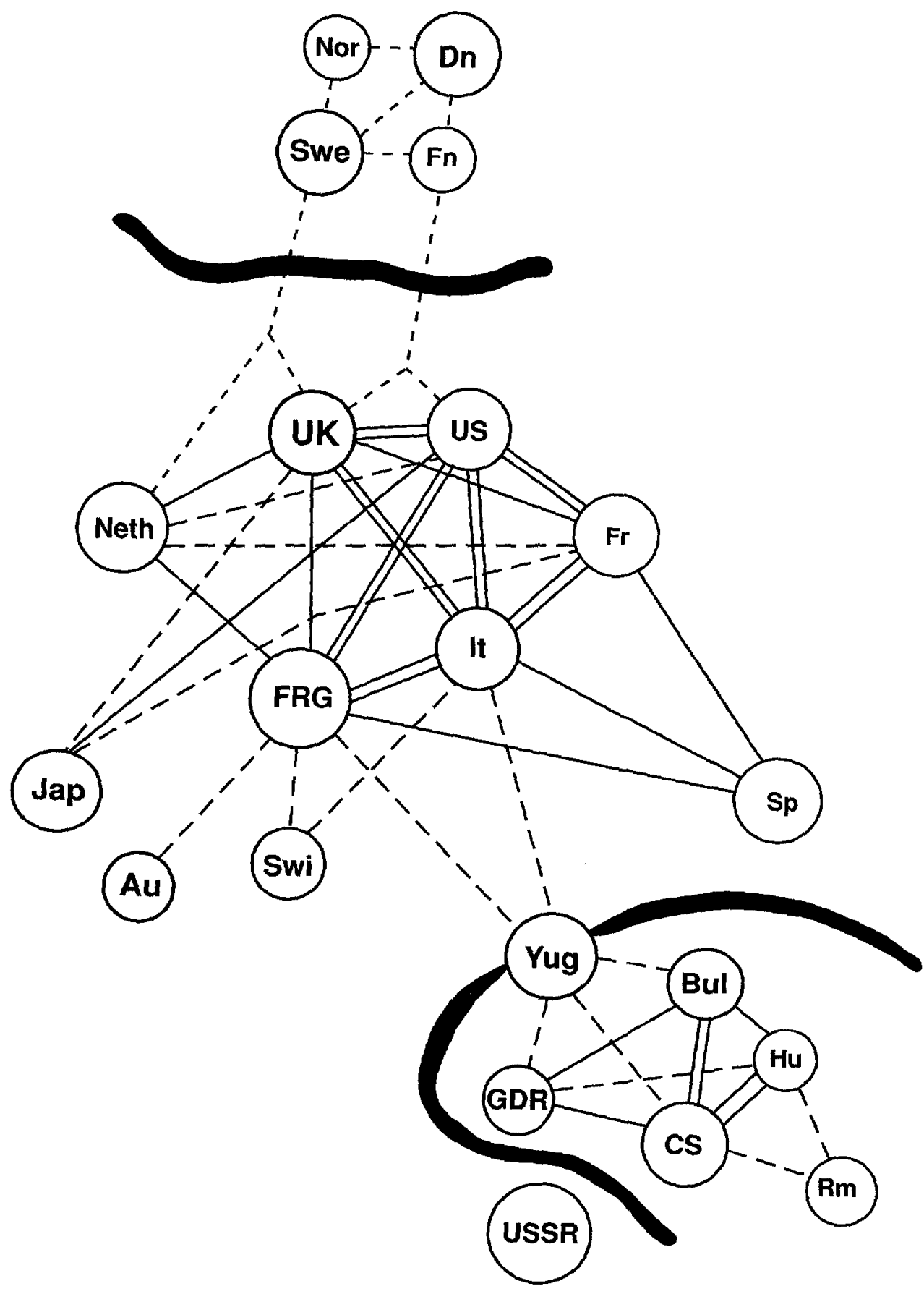

